\title{
Genesis of trondhjemite by low-pressure low-melt fraction anatexis of hornblende-gabbro at Alvand Plutonic Complex (Hamedan, NW Iran): insights from geochemical modelling
}

\author{
Federico Lucci ${ }^{1}$ (I) $\cdot$ Adel Saki $^{2} \cdot$ Mirmohammad Miri $^{2} \cdot$ Ahmad Rabiee $^{1} \cdot$ John Charles White $^{3}$
}

Received: 12 May 2021 / Accepted: 22 July 2021 / Published online: 16 August 2021

(C) The Author(s) 2021

\begin{abstract}
Amphibole-dominated dehydration melting of gabbro is the primary process responsible for the genesis of adakites, low-K tonalites, modern trondhjemites, and plagiogranites as well as Archean tonalite-trondhjemite-granodiorite suites that represent the earliest examples of continental crust. Previous literature has mostly focused on the role of Al-rich amphibole during anatexis of a mafic source and many of these studies have investigated this process through experimental melting runs. However, due to experimental boundary conditions, little is known about partial melting of amphibole-bearing mafic rock at temperatures $<800^{\circ} \mathrm{C}$ for upper crustal conditions (pressure $<500 \mathrm{MPa}$ ). Classic and forward thermobarometric modelling suggests that in situ trondhjemite leucosomes, hosted by Cheshmeh-Ghasaban mafic metatexites (Alvand Plutonic Complex, Hamedan, NW Iran), represent a rare natural case study of a low-temperature incipient amphibole-dominated anatectic event of a mafic source with a primary assemblage $(\mathrm{Pl}+\mathrm{Hbl}+\mathrm{Cpx}+\mathrm{Bt}+\mathrm{Opx})$ typical of a hornblende-bearing gabbroic rock.
\end{abstract}

Keywords Anatexis $\cdot$ Trondhjemite $\cdot$ Partial melting modelling $\cdot$ Thermobarometry $\cdot$ Sanandaj-Sirjan Zone $\cdot$ Iran

\section{Introduction}

Crustal anatexis characterized by melt segregation and extraction is considered one of the key processes for the genesis of large volumes of felsic magmas and therefore also for continental crustal growth and differentiation (e.g., Clemens 1990; Vielzeuf and Vidal 1990; Johannes and Holtz 1996; Clemens and Watkins 2001; Kriegsman 2001; Ratajeski et al. 2005; Sisson et al. 2005; Gao et al. 2016; Rossetti et al. 2020; Saki et al. 2021). Furthermore, crustal anatectic events mainly

Responsible Editor: Domenico M. Doronzo

This paper was selected from the 3rd Conference of the Arabian Journal of Geosciences (CAJG), Tunisia 2020

Federico Lucci

federico.lucci@uniroma3.it

1 Dipartimento di Scienze, Sez. Scienze Geologiche, Università Degli Studi Roma Tre, Rome, Italy

2 Department of geology, Faculty of Earth sciences, Shahid Chamran University of Ahvaz, Ahvaz, Iran

3 Department of Geosciences, Eastern Kentucky University, Richmond, KY 40475, USA occur through amphibole-, biotite-, and muscovitedehydration melting reactions (e.g., Clemens 1990; Gao et al. 2016 and references therein) capable of producing melts with particular chemical characteristics (e.g., Clemens 1990; Clemens and Stevens 2012; Johannes and Holtz 1996; Patiño Douce 1999; Castro 2013). Over the past few years, melting experiments have been performed at pressures $(\mathrm{P})$ up to 3.2 $\mathrm{GPa}$ and temperatures (T) up to $1100^{\circ} \mathrm{C}$ (see Gao et al. 2016, and references therein) to help understand closed-system felsic magma generation from partial melting of protoliths various compositions (e.g., Beard and Lofgren 1991; Castro et al. 1999; Sisson et al. 2005; Laurie and Stevens 2012; Skjerlie and Patiño Douce 1995, 2002; Watkins et al. 2007; Conrad et al. 1988; Skjerlie and Johnston 1996; Vielzeuf and Montel 1994; Montel and Vielzeuf 1997; Castro et al. 1999; García-Arias et al. 2012). A review of the existing chemistry data of experimental melts from mafic to metapelitic protoliths was recently published by Gao et al. (2016). Among all these studies, there was great emphasis on experimental and natural evidence for amphibole-dominated dehydration melting of mafic magmatic and metamorphic sources such as basalts, andesites, gabbros, greenstones, amphibolites, and eclogites (e.g., Barker and Arth 1976; Barker 1979; Beard and Lofgren 1991; Sisson et al. 2005; Ratajeski et al. 2005; Saki 
et al. 2021), because this is one of the processes that may control the genesis of dacites (e.g., Beard and Lofgren 1991), adakites (e.g., Rossetti et al. 2014), modern low-K tonalites and trondhjemites (e.g., Barker and Arth 1976; Beard and Lofgren 1991; Sisson et al. 2005; Ratajeski et al. 2001, 2005; García-Casco et al. 2008; Saki et al. 2021), plagiogranites (e.g., Koepke et al. 2005), and, most significantly, the Archean tonalite-trondhjemite-granodiorite (TTG) suites believed to provide the first evidence of Earth's continental crust (e.g., Barker and Arth 1976; Moyen and Stevens 2006).

With the goal of contributing to the understanding of the genesis of trondhjemite leucosomes through partial melting of hornblende-bearing mafic rocks, this paper is focused on the role of the dominant protolith-forming minerals during incipient crustal anatectic events. In particular, this work is intended as a companion paper of Saki et al. (2021) and uses part of its geochemical dataset from the Cheshmeh-Ghasaban (CG) mafic migmatite suite (Hamedan, NW Iran) where the connection between a gabbro protolith and in situ trondhjemite leucosomes has been demonstrated (Saki et al. 2020, 2021). Results are discussed in the context of the existing literature. This study, exploring the $\mathrm{CG}$ mafic metatexites, provides new evidence on how the very early stage of partial melting of a hornblende-bearing mafic rock is developed in upper crust environment.

\section{Geological setting}

The Alvand plutonic complex is located within the SanandajSirjan Zone (hereafter SaSZ) of Iran (Fig. 1a), a distinctive $\approx 1000 \mathrm{~km}$ long and $\approx 150 \mathrm{~km}$ wide NW-SE trending crustal terrane (Stöcklin 1968), tectonically delimited by the Urumieh-Dokhtar Magmatic Belt (UDMB) and by the Zagros suture zone, at its northeastern and southwestern ends, respectively. The SaSZ is characterized by a Cadomian $(\approx 500$ $600 \mathrm{Ma}$ ) basement (e.g., Stöcklin and Nabavi 1973; Ghasemi and Talbot 2006; Hassanzadeh et al. 2008; Malek-Mahmoudi et al. 2017; Azizi and Stern 2019; Moghadam et al. 2020, 2021) consisting of greenschist to amphibolite metamorphic rocks intruded by Jurassic-Cretaceous magmas (Mohajjel et al. 2003; Ghasemi and Talbot 2006; Hassanzadeh and Wernicke 2016; Azizi et al. 2018a, b; Saki et al. 2020). It has been interpreted as the southwestern portion of the Iranian microcontinent (Hassanzadeh et al. 2008; Hosseini et al. 2015; Azizi et al. 2016, 2018a). Since the work of Eftekharnejad (1981), the SaSZ has been commonly divided in northern and southern sectors; however, recently, Azizi and Stern (2019) proposed a subdivision in three subzones from north to south: Northern-SaSZ (N-SaSZ), Central SaSZ (CSaSZ), and Southern SaSZ (S-SaSZ). In particular, the C$\mathrm{SaSZ}$ is bounded with the structural zones of Baneh-
Mianeh-Ardabil in the north (Rabiee et al. 2020) and the continuation of Daruneh-Naeen fault in the south (Fig. 1a).

The C-SaSZ, where the Alvand plutonic complex and the study area are located, is characterized by (i) Cadomian basement dominated by metagranites and amphibolites (Badr et al. 2018; Azizi and Stern 2019); (ii) the Jurassic metamorphic complex (Mohajjel and Fergusson 2000; Mohajjel et al. 2003; Agard et al. 2005; Hassanzadeh and Wernicke 2016; Azizi and Stern 2019) with protoliths interpreted as mafic to felsic volcanic rocks interbedded with carbonates and siliciclastic materials deposited over a thin Cadomian crust in a marine basin setting (e.g., Mohajjel et al. 2003; Baharifar et al. 2004; Hassanzadeh and Wernicke 2016; Azizi et al. 2018a, b); and (iii) the Jurassic to Early Cretaceous gabbro to granite intrusive complexes (Saki et al. 2021 and references therein). The latter magmatic activity heated the pre-existing rocks and generated Buchan-type thermo-metamorphic contact aureoles characterized by $\mathrm{Al}_{2} \mathrm{SiO}_{5^{-}}$ bearing hornfels up to migmatization (e.g., Baharifar et al. 2004; Agard et al. 2005; Sepahi et al. 2009, 2018, 2019, 2020; Shahbazi et al. 2010, 2014; Mahmoudi et al. 2011; Hassanzadeh and Wernicke 2016; Saki et al. 2020).

The Jurassic Alvand plutonic complex (Fig. 1a, b) in the Hamedan area, with an exposed area of $>400 \mathrm{~km}^{2}$, is one of the largest batholiths intruded into the C-SaSZ (e.g., Aliani et al. 2012). It consists of a composite mafic to felsic plutonic complex with a main body made up of porphyritic granular biotite-bearing granite (e.g., Sepahi 2008; Sepahi et al. 2018, 2020; Shahbazi et al. 2010; Aliani et al. 2012; Sheikhi Gheshlaghi et al. 2020). Diffused leucogranitic, aplitic, and pegmatitic dikes and dikes-swarms intrude both the whole Alvand complex and its contact aureole (e.g., Aliani et al. 2012; Sepahi 2008; Sepahi et al. 2018, 2020; Shahbazi et al. 2010; Sheikhi Gheshlaghi et al. 2020). Mafic intrusive rocks are mostly represented by pegmatoid and microcrystalline gabbros and diorites that outcrop as stocks and dikes (e.g., Shahbazi et al. 2010; Aliani et al. 2012; Saki et al. 2020, 2021) and are mainly found in the northern part of the Alvand complex, at the Cheshmeh-Ghasaban (CG) locality (Fig. 1b). Minor occurrences of these mafic rocks are also observed in the eastern sector of the Alvand complex, in the Simin-Khaku locality (Eghlimi 1998; A.A. Sepahi, personal communication). Existing literature on the CG gabbros (Eshraghi and Mahmoudi Gharai 2003; Sepahi et al. 2009; Shahbazi et al. 2010; Yang et al. 2018; Saki et al. 2020) permits their discrimination between (i) hornblende-free olivinegabbros (hereafter Ol-gabbro) with pyroxenite lenses and (ii) hornblende-bearing gabbros (hereafter Hbl-gabbro) and diorites. A primary contact between these two gabbroic lithotypes is locally observed (e.g., Saki et al. 2021); however, a detailed field study is still missing. The Alvand complex has been dated by zircon U-Pb method (Shahbazi et al. 2010; Mahmoudi et al. 2011; Chiu et al. 2013; Sepahi et al. 2018, 

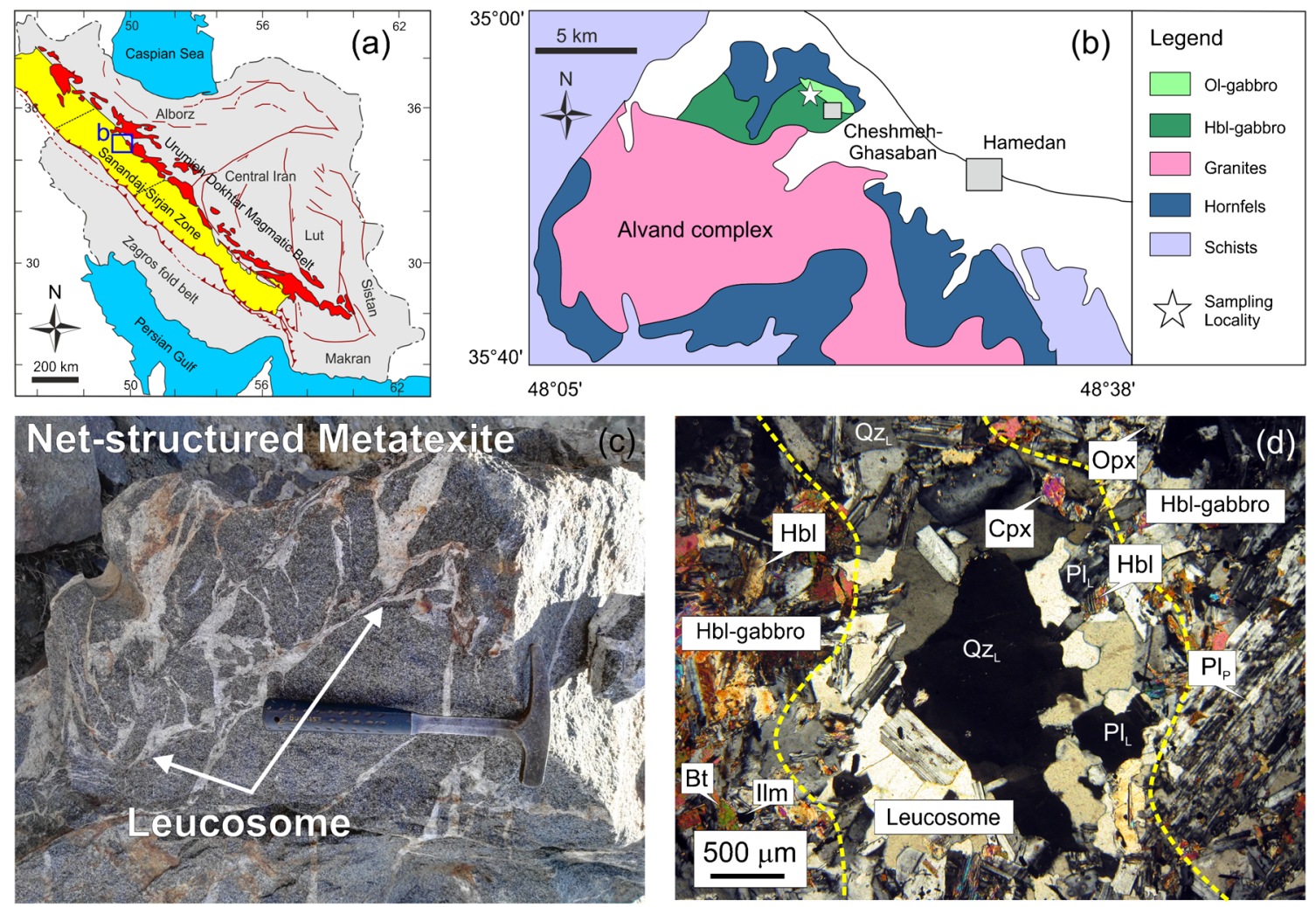

Fig. 1 Geological framework. a Schematic geological map of Iran (modified after Ghasemi and Talbot 2006; Saki et al. 2021). The Sanandaj-Sirjan zone is indicated in yellow. The blue square is the study area presented in b. b Simplified geological map of the Alvand plutonic complex (after Saki et al. 2021). The white star indicates the CheshmehGhasaban metatexite migmatites and the sampling locality. c Field observation: an example of the outcropping mafic metatexite migmatite

characterized by net-structured texture and in situ leucosomes. d Petrography: the Hbl-gabbro protolith hosting an in situ leucosome micropatch. The Hbl-gabbro shows a holocrystalline texture with a primary assemblage made up of plagioclase $\left(\mathrm{Pl}_{\mathrm{P}}\right)$, hornblende $(\mathrm{Hbl})$, clinopyroxene $(\mathrm{Cpx})$, orthopyroxene $(\mathrm{Opx})$, biotite $(\mathrm{Bt})$, and ilmenite $(\mathrm{Ilm})$, whereas the leucosome is characterized mainly by a plagioclase $\left(\mathrm{Pl}_{\mathrm{L}}\right)$ and quartz $\left(\mathrm{Qz}_{\mathrm{L}}\right)$ association

2020; Zhang et al. 2018a, b; Yang et al. 2018) which reveals a prolonged Jurassic magmatic history from $\approx 167$ to $150 \mathrm{Ma}$. These geochronology studies suggest that CG gabbros emplaced at $\approx 161-167 \mathrm{Ma}$ (Shahbazi et al. 2010; Yang et al. 2018). Furthermore, Sepahi et al. (2013) used classic thermobarometry modelling to estimate emplacement temperatures of $1200-1300^{\circ} \mathrm{C}$ and $900-1100{ }^{\circ} \mathrm{C}$ for Ol-gabbros and Hbl-gabbros, respectively, at crustal conditions of $\approx 5-6 \pm 2.5$ kbar for both.

The intrusive Alvand plutonic complex generated a welldeveloped thermo-metamorphic aureole made up of cordierite-andalusite-sillimanite-bearing hornfels and cordierite-bearing migmatites (e.g., Sepahi et al. 2019; Saki et al. 2020) in the local low-grade regional metamorphic basement (known in literature as "Hamedan Phyllite," e.g., Mohajjel et al. 2003). Peak conditions for the thermal aureole were estimated at $\sim 750{ }^{\circ} \mathrm{C}$ and $4 \mathrm{kbar}$ (Sepahi 2008 , Sepahi et al. 2013; Sepahi et al. 2009, 2013, 2020; Saki et al. 2012, 2020; Baharifar et al. 2004; Shahbazi et al. 2014; Sheikhi Gheshlaghi et al. 2020). The metapelitic migmatites show a $\mathrm{U}-\mathrm{Pb}$ zircon age of $\sim 170 \mathrm{Ma}$ (Sepahi et al. 2019), and are mostly found in the eastern (Simin-Khaku locality) and

southern (Tuyserkan locality) sectors of the inner aureole (e.g., Saki et al. 2021). These migmatites are characterized by the diffuse occurrence of S-type leucosomes and pegmatites (e.g., Sepahi et al. 2019; Sheikhi Gheshlaghi et al. 2020; Saki et al. 2012, 2020, 2021).

The presence of mafic metatexite migmatites, characterized by the presence of both in situ and in source trondhjemite leucosomes within the $\mathrm{CG} \mathrm{Hbl-gabbro} \mathrm{protolith,} \mathrm{was} \mathrm{reported}$ and investigated by Saki et al. (2020, 2021). Saki et al. (2020) studied these mafic migmatites by integrating (i) field observations, (ii) microfabric and textures, and (iii) mineral and bulk rock chemistry and investigated the migmatization event through qualitative analysis of partial melting reactions and classic and forward thermobarometry. Saki et al. (2021) followed this with a quantitative investigation of the gabbrotrondhjemite connection utilizing (i) major-element mass balance modelling, (ii) trace and REE elements equilibrium batch melting (EBM) modelling, (iii) pseudosection analysis applied to the Hbl-gabbro protolith, and (iv) a preliminary comparison between trondhjemite leucosomes and the chemistry of experimental melts from literature. They concluded that an origin for in situ trondhjemite leucosomes are compatible with 
$1-2 \%$ partial melting of the Hbl-gabbro through an amphibole-dehydration melting process near the solidus at mid-to-upper crustal conditions of $\approx 700-750{ }^{\circ} \mathrm{C}$ and $300-$ $450 \mathrm{MPa}$.

\section{Field observation and petrography}

In this companion paper, we present the field occurrences, petrography, and mineralogy characterizing the studied Hblgabbro protolith and the in situ trondhjemite leucosomes.

The CG gabbros, with an area of $>20 \mathrm{Km}^{2}$ (Fig. 1b), represent the most significant outcrop of mafic rocks in the Alvand complex. Here both Ol-gabbro and Hbl-gabbro are exposed and locally a primary contact is recognized (Saki et al. 2021 and references therein). Close to this contact, the Hbl-gabbro shows evidence for migmatization (Fig. 1c) characterized by the presence of in-source and in situ leucosomes (sensu Sawyer 2008) in millimetric- to metric-scale veins, dikes, patches, net structure, veinlets, and lenses. Locally, schollen migmatite fabric is observed. The low volume of leucosome $(<10 \mathrm{vol} \%)$ is typical of a metatexite migmatite (e.g., Sawyer 2008). To note, Sepahi et al. (2009) had already reported the thermally metamorphosed gabbros and Eshraghi and Mahmoudi Gharai (2003) previously documented "agmatites in gabbros" in the "Tuyserkan" quadrangle geological map, whereas no leucosome outcrop was found or documented in the Ol-gabbros (Saki et al. 2021).

The Hbl-gabbro (Fig. 1d) is characterized by a holocrystalline hypidiomorphic fine- to coarse-grained isotropic texture with a preserved primary assemblage consisting of plagioclase (40-50 vol\%; $\mathrm{An}_{57-60} \mathrm{Ab}_{40-42} \mathrm{Or}_{0-1}$ ), hornblende (30-35 vol\%, magnesio-hornblende), clinopyroxene (10-20 vol\%, diopside-rich augite), biotite (<10 vol\%, eastonite), quartz $(<5$ vol\%), and orthopyroxene $(<5$ vol\%, hypersthene). In decreasing order of abundance, accessory minerals are ilmenite, apatite, titanite, and zircon. In agreement with Saki et al. (2021), nearer the leucosomes, (i) plagioclase shows subrounded morphology with lobate margins, (ii) hornblende is characterized by clinopyroxene + orthopyroxene replacement, and (iii) biotite shows generally preserved primary textures. Mafic selvedges made up of hornblende and biotite in sheaf textures are also locally observed.

The trondhjemite leucosomes (Fig. 1d) are characterized by a holocrystalline, hypidiomorphic to allotriomorphic hololeucocratic granular texture with a magmatic assemblage dominated by euhedral to anhedral plagioclase (up to 60 vol\%, $\mathrm{An}_{26-30} \mathrm{Ab}_{68-72} \mathrm{Or}_{0-2}$ ) and anhedral quartz (up to 40 vol\%), and rare k-feldspar locally showing granophyric textures. Rare xenomorphic pyroxenes (diopside-rich augite and hypersthene) are also observed within the leucosomes. Melanosomes, made up of plagioclase (up to $50 \mathrm{vol} \%$ ), clinopyroxene (up to $40 \mathrm{vol} \%$ ), hornblende (up to $30 \mathrm{vol} \%$ ), and biotite ( $<5$ vol\%), are commonly observed close to leucosomes. Saki et al. (2021) interpreted these melanosomes as a melt residuum (sensu Taylor and Stevens 2010; Rossetti et al. 2020) following anatexis.

\section{Methodology}

Five samples from the CG Hbl-gabbro protolith and five samples from in situ trondhjemite leucosomes were selected for whole-rock analyses. Samples were analysed for major, trace, and REE elements at Activation Laboratories (Canada) by ICP-OES and ICP-MS (code 4Lithoresearch). For major elements, the uncertainty (1s) is estimated less than $2 \%$ for concentrations higher than $5 \mathrm{wt} \%$, and less than $5 \%$ for concentrations between 0.1 and $5 \mathrm{wt} \%$. For trace elements, the precision is $5 \%$ and $10 \%$ for the values in the ranges $1-100 \mathrm{ppm}$ and $0.1-1 \mathrm{ppm}$, respectively. Whole-rock chemistry is presented in Table 1. The dataset is integrated with analyses of nine leucosome from Saki et al. $(2020,2021)$ and one Hbl-gabbro from Saki et al. (2021) collected from the same studied outcrops. These data are also reported in Table 1 for comparison. The total alkali vs. silica (TAS) diagram (after Middlemost 1994) is here chosen as proxy diagram for the purpose of a homogeneous dataset presentation. In the following, we adopted the mineral abbreviation recommended by Whitney and Evans (2010).

\section{Whole-rock geochemistry}

The Hbl-gabbro studied samples show (i) LOI < 1.33 wt $\%$ (average $0.99 \mathrm{wt} \%$ ) and (ii) the invariably absence of secondary phases such as epidote, chlorite, and tremolite-actinolite amphibole, suggesting a negligible degree of alteration. They are characterized by $48.46-51.20 \mathrm{wt} \% \mathrm{SiO}_{2}$, with $13.75-$ 17.13 wt $\% \mathrm{Al}_{2} \mathrm{O}_{3}, 7.33-10.09 \mathrm{Fe}_{2} \mathrm{O}_{3} *, 11.48-13.54$ wt $\%$ $\mathrm{CaO}, 0.94-1.20 \mathrm{wt} \% \mathrm{TiO}_{2}$, and 7.71-8.29 wt $\% \mathrm{MgO}$. On the total alkali vs. silica (TAS) diagram for plutonic rocks (after Middlemost 1994), all samples fall in the field of "gabbro" (Fig. 2a). The Hbl-gabbro shows trace elements contents of 423-545 ppm Sr, 13-18 ppm Y, ₹55-72 ppm SLREE, and $\approx 9-11$ SHREE. In the chondrite (Ch-) normalized diagram (Fig. 2b; Sun and McDonough 1989), the Hbl-gabbro samples are characterized by homogeneous fractionated patterns with $\mathrm{La}_{\mathrm{N}} / \mathrm{Yb}_{\mathrm{N}}$ and $\mathrm{Dy}_{\mathrm{N}} / \mathrm{Yb}_{\mathrm{N}}$ ranging $6.20-8.67$ and $0.98-1.60$, respectively, with a positive $\mathrm{Eu}$ anomaly $\left(\mathrm{Eu} / \mathrm{Eu}^{*}=\left[\mathrm{Eu}_{\mathrm{N}} /\right.\right.$ $\left.\left.\left(\mathrm{Sm}_{\mathrm{N}} \cdot \mathrm{Gd}_{\mathrm{N}}\right)^{1 / 2}\right]=1.05-1.22\right)$.

The trondhjemite leucosomes are characterized by high $\mathrm{SiO}_{2}(76.45-80.08 \mathrm{wt} \%)$ and very low $\mathrm{MgO}(0.11-0.55$ wt $\%), \mathrm{Fe}_{2} \mathrm{O}_{3} *(0.21-1.36 \mathrm{wt} \%), \mathrm{TiO}_{2}(0.03-0.16 \mathrm{wt} \%)$, and $\mathrm{CaO}(1.27-2.89 \mathrm{wt} \%)$ contents. The $\mathrm{Al}_{2} \mathrm{O}_{3}$ content is in the range $12.38-13.99 \mathrm{wt} \%$, and the $\mathrm{Na}_{2} \mathrm{O}(3.18-5.01 \mathrm{wt} \%)$ is 
由. गुँ

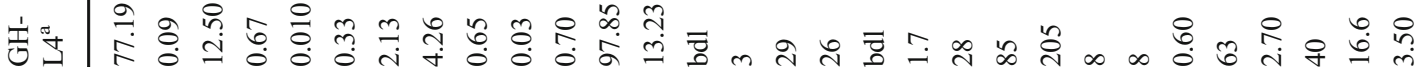

$\therefore$

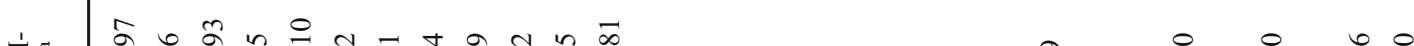

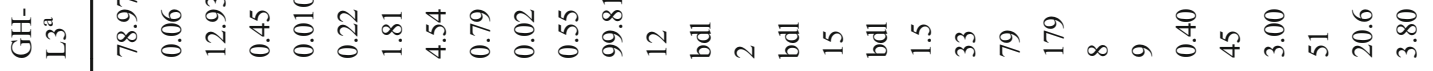
$\stackrel{4}{\sim}$ 岁热 กิ 8 min 8 กิ

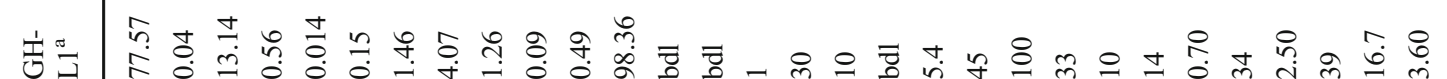

$+\infty$

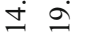

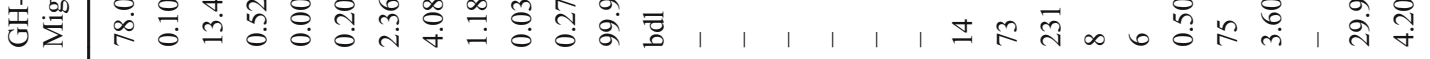
유요

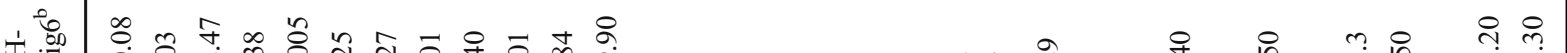

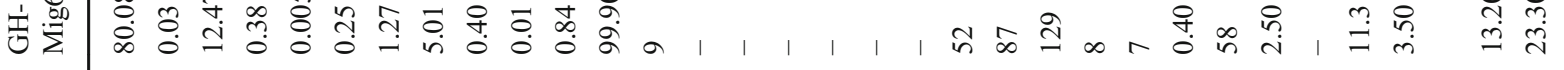

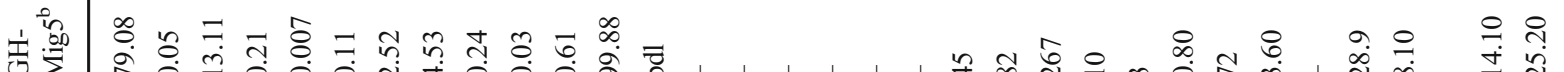

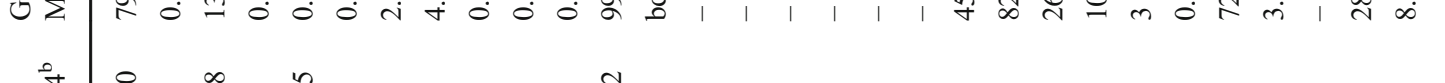

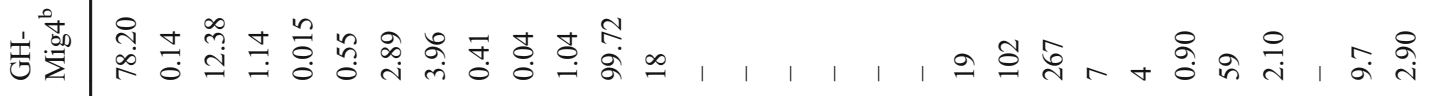
b 눙 Uु b)

म Uू b

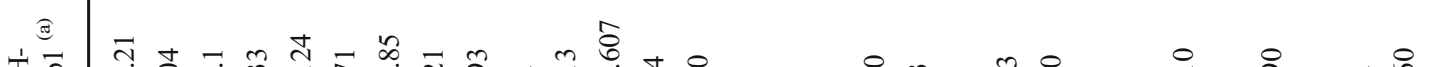

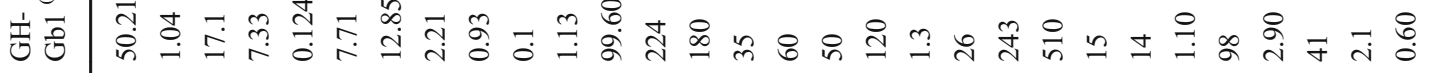

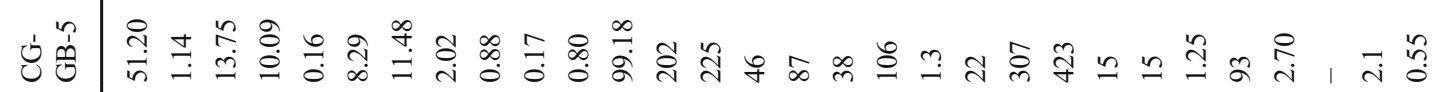

b่

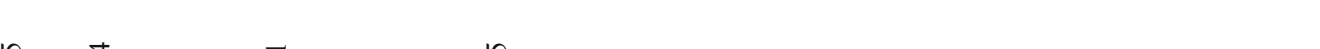

U⿺辶寸

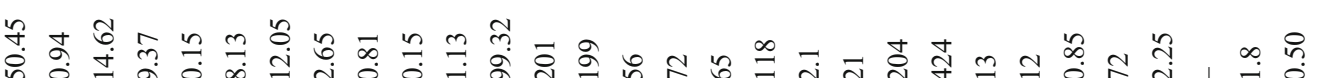
î:

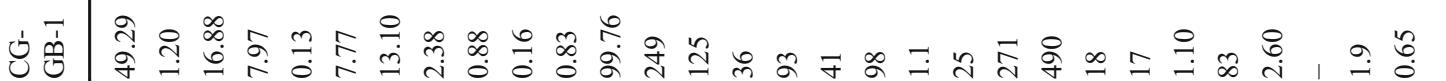




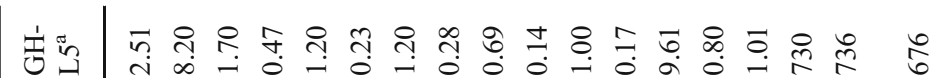

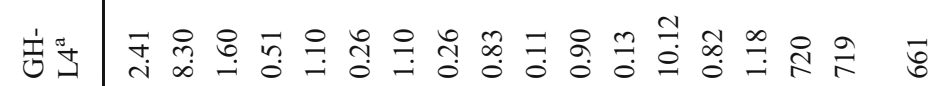

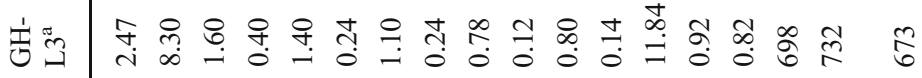

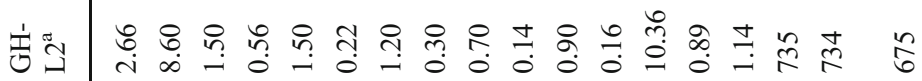
出

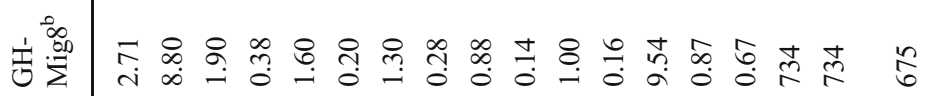
岃点 嵌 声苟

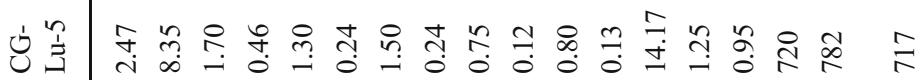
Uป

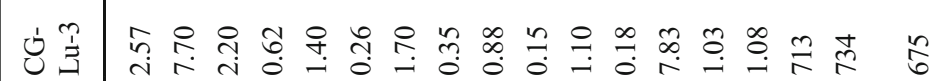

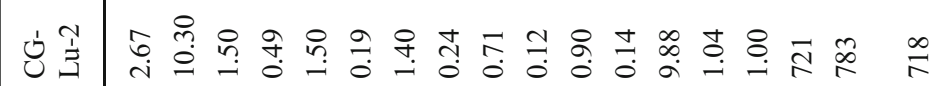
b 出

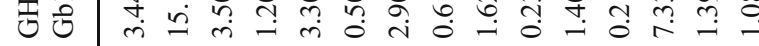

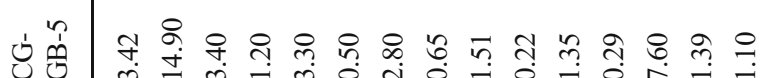

U⿺辶寸

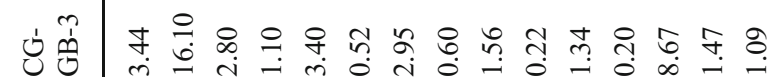

نํํㅂ

竞

|

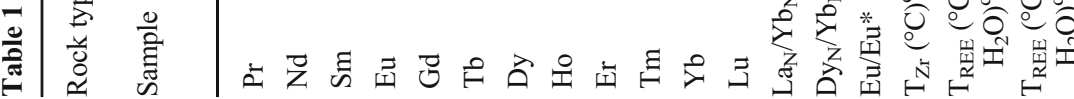

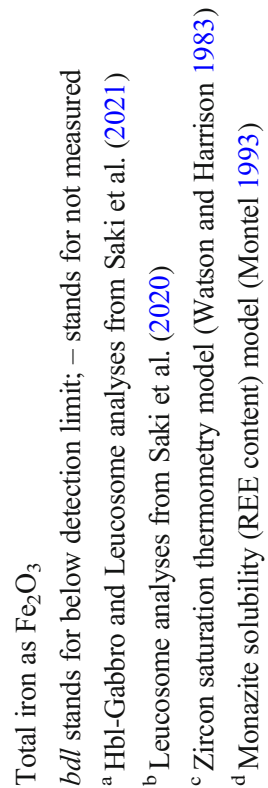




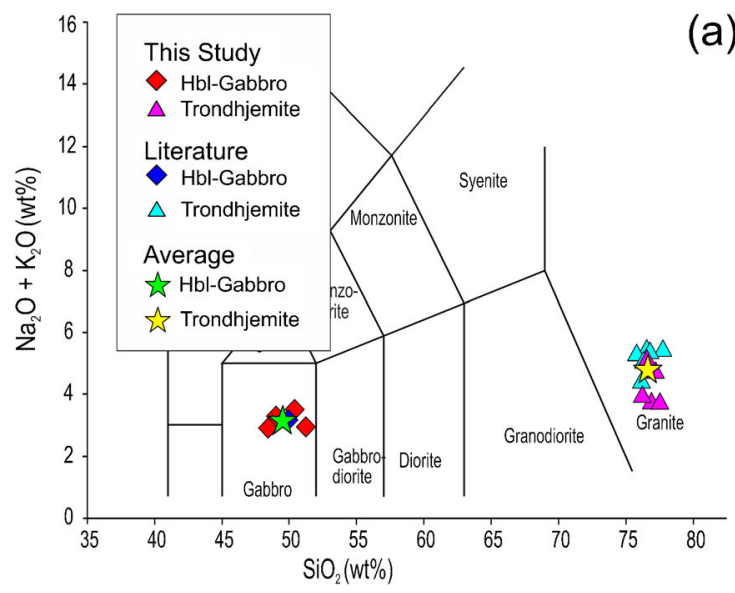

$\mathrm{Na}_{2} \mathrm{O}$

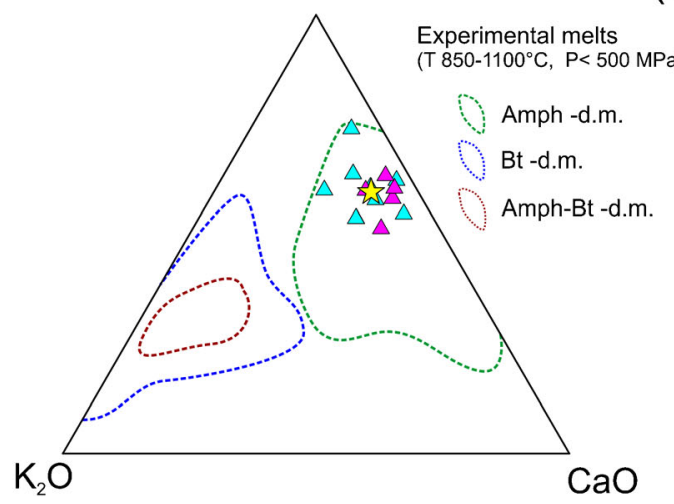

Fig. 2 Whole-rock geochemistry. a Total alkali versus silica (TAS) diagram for plutonic rocks (after Middlemost 1994; Le Maitre et al. 2002). All the major elements data have been recalculated to $100 \mathrm{wt} \%$ on anhydrous basis with $\mathrm{FeO}^{*}$ as total $\mathrm{FeO}$. b Chondrite-normalized rare earth elements (REEs) diagram (Sun and McDonough 1989). c CaO-Na $\mathrm{Na}_{2} \mathrm{O}$ $\mathrm{K}_{2} \mathrm{O}$ diagram for Cheshmeh-Ghasaban leucosomes. The fields of experimental melts produced at low pressure $(P<500 \mathrm{MPa})$ through amphibole

always higher than the $\mathrm{K}_{2} \mathrm{O}(0.24-1.26 \mathrm{wt} \%)$ content. In the TAS diagram (Fig. 2a), these leucosomes plot in the "Granite" field. They have 33-267 ppm Sr, 7-13 ppm Y, 34-124 ppm $\mathrm{Zr}, \approx 43-55 \mathrm{ppm}$ SLREE, and $\approx 4-6 \mathrm{ppm}$ SHREE. In the Ch-normalized diagram (Fig. 2b), leucosome samples are enriched in LREE with $\mathrm{La}_{\mathrm{N}} / \mathrm{Yb}_{\mathrm{N}}$ values in the range 7.83-14.17 and show depleted concave upward profiles with HREE flat patterns $\left(\mathrm{Dy}_{\mathrm{N}} / \mathrm{Yb}_{\mathrm{N}}\right.$ ranging $0.73-$ $1.25)$. The $\mathrm{Eu}$ anomaly is variable $\left(\mathrm{Eu} / \mathrm{Eu}^{*} 0.67-1.41\right.$; mean value 1.02), which indicates a variable role for plagioclase during their genesis (e.g., $\mathrm{Hu}$ et al. 2016). The high- $\mathrm{SiO}_{2}$ low- $\mathrm{Al}_{2} \mathrm{O}_{3}$ trondhjemite character (Barker and Arth 1976; Le Maitre et al. 2002) previously identified by Saki et al. (2021) can be confirmed based on (i) modal mineralogy (QAP diagram of Streckeisen 1976 in Le Maitre et al. 2002; not shown), (ii) $\mathrm{Na}_{2} \mathrm{O}-\mathrm{CaO}-\mathrm{K}_{2} \mathrm{O}$ contents (Fig. 2c), (iii) the Ab-An-Or normative diagram (Fig. 2d; Barker 1979), and (iv) the $\mathrm{Al}_{2} \mathrm{O}_{3}(<15 \mathrm{wt} \%)$ content. Furthermore, on the $\mathrm{Ab}-\mathrm{An}-\mathrm{Or}$ diagram (Fig.

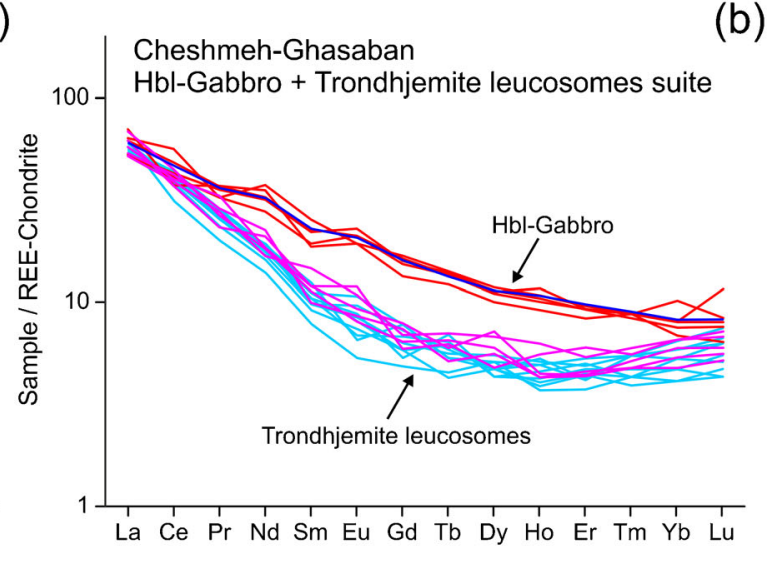

(c)

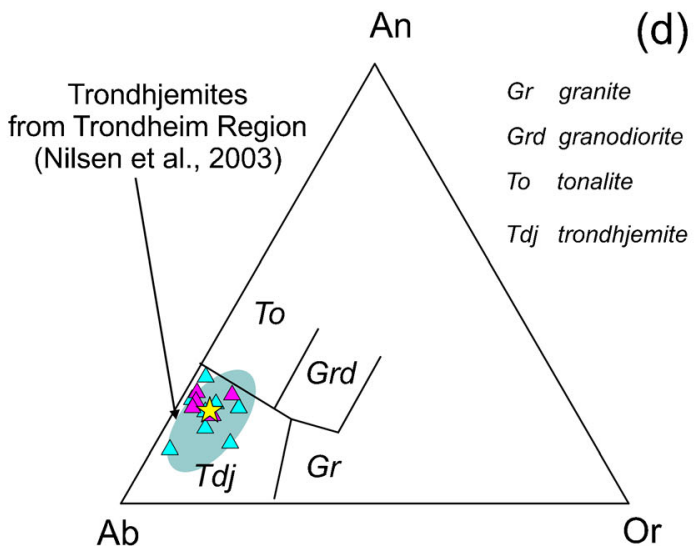

(green field), biotite (blue field), and amphibole+biotite (dark red) dehydration melting are also indicated. d Normative An-Ab-Or diagram for the studied leucosomes. Literature data for "Hbl-Gabbro" and "Trondhjemite" are from Saki et al. (2021). Field of trondhjemites from Trondheim Region (Norway; cyan field, Nilsen et al. 2003) is also reported

2d), all the studied samples fall in the field of typical trondhjemites (Nilsen et al. 2003).

For the purpose of partial melting modelling using major elements, trace elements ( $\mathrm{Sr}, \mathrm{Y}$ ), and REE (Dy, Yb), we calculated the compositions for average Hbl-gabbro protolith (Av-Gb; green star in diagrams of Figs. 2 and 3) and trondhjemite leucosome (Av-Lc; yellow star in diagrams of Figs. 2, 3, and 7). They are presented in Table 2.

\section{Workflow}

Starting from the same mineral assemblage $(\mathrm{Pl}+\mathrm{Hbl}+\mathrm{Cpx})$ used in Saki et al. (2021) and using the current calculated protolith and leucosome average compositions, we test the equilibrium batch melting (EBM) model by integrating biotite and orthopyroxene (analyses of Saki et al. 2021) to (i) refine the $K_{D}$ coefficients characterizing this partial melting event, (ii) to constrain the role of all the main protolith-forming 

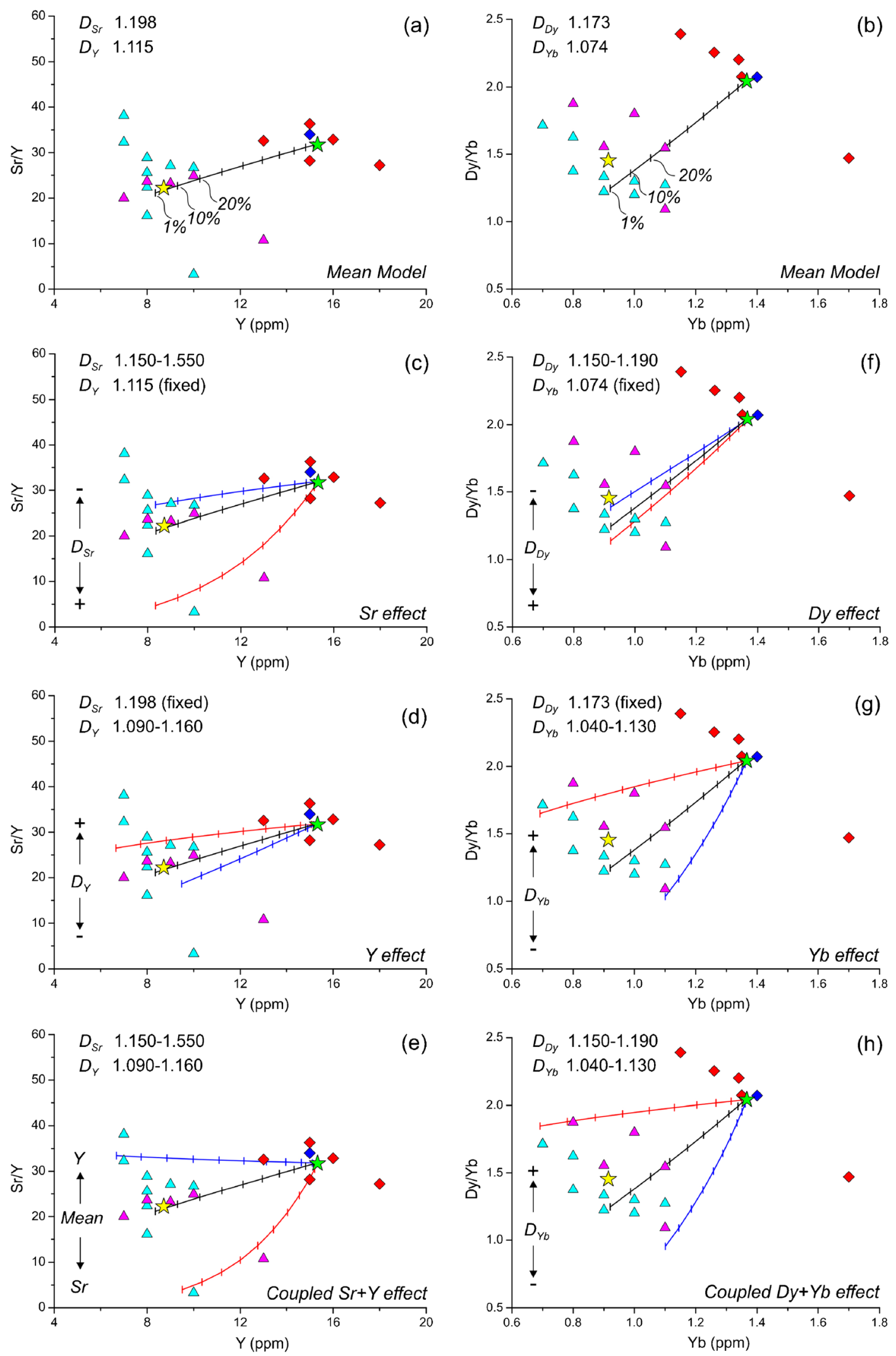

\section{This Study}

Literature

Average

Hbl-Gabbro

Hbl-Gabbro

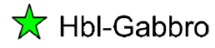

Modal Batch Melting Model

$\triangle$ Trondhjemite

$\triangle$ Trondhjemite

饮 Trondhjemite

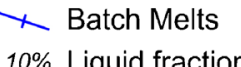


Fig. 3 (a) $\mathrm{Y}$ vs $\mathrm{Sr} / \mathrm{Y}$ and (b) $\mathrm{Yb}$ vs $\mathrm{Dy} / \mathrm{Yb}$ diagrams illustrating the genesis of the trondhjemite leucosomes via equilibrium batch melting (EBM) modelling and starting from the Av-Gb bulk average gabbroic protolith compositions. The effect of the primary $\mathrm{Pl}+\mathrm{Hbl}+\mathrm{Cpx}$ assemblage on the EBM process is also presented for Sr-Y (c-e) and Dy-Yb (f-h) systems. Bulk rock/melt partition coefficients used for EBM models are reported in diagrams. The calculated EBM curves represent, for every model, the Shaw (1970) modal batch melting solution. Batch melts stands for leucosomes. The percentages indicate the amount (wt\%) of melt generated

mineral phases, and (iii) to better constrain through a forward modelling the P-T conditions of the Hbl-gabbro anatexis.

The major-element mass balance model of Bryan et al. (1969) was used in Saki et al. (2021) to test the hypothesis of EBM (White et al. 2009; Lucci et al. 2016) for the genesis of trondhjemite leucosomes from the partial melting of the Hbl-gabbro. In EBM modelling, it is assumed that Residual Assemblage (Minerals) = Protolith Source - Leucosome. If the composition of the protolith is assigned to matrix $b$, and all elemental equations are solved for $b$, then $b=$ Leucosome + Minerals. When the chemistry of leucosome and minerals are known and expressed in matrix $A$, it is possible to determine their proportion (in matrix $c$ ) by least square approximation method. The similarity between the residual matrix $b$ ' (with $b^{\prime}=c \mathrm{X} A$ ) and the matrix $b$ (the protolith) is quantified through the sum of the square of the residuals $\left(\Sigma r^{2}\right)$ as the following:

$\sum r^{2}=\sum_{i-1}^{n}\left(b_{i}^{\prime}-b_{i}\right)^{2}$

Table 2 Average compositions for EBM modelling
Models are considered acceptable when $\Sigma r^{2}<1.0$. The proportion of the leucosome is expressed with the variable $F$ in matrix $c$.

Considering (i) the in situ character of the leucosomes and their equilibrium with the residuum until the end of the anatexis, (ii) the paucity/absence of gabbro remnants within the leucosomes, and (iii) the results obtained by Saki et al. (2021), it is then assumed the studied partial melting event is compatible with an equilibrium batch melting process (Shaw 1970; Zou 1998; Ersoy 2013), where the proportions of the involved mineral phases were those of the magmatic assemblage of the protolith. Following Saki et al. (2021), we use the Shaw (1970) equation chosen for equilibrium batch melting:

$C_{L}=\frac{C_{0}}{D_{0}+F\left(1-D_{0}\right)}$

where $C_{0}$ is the elemental concentration in the protolith, $D_{0}$ is the bulk mineral/melt partition coefficient, $F$ is the fraction of produced melt, and $C_{L}$ is the corresponding calculated elemental concentration in the batch melt. The selected elements are Sr (LILE), Y (HFSE), and Dy and Yb (HREE). The element bulk partition coefficients $\left(D_{S r}, D_{Y}, D_{Y b}\right.$, and $\left.D_{D y}\right)$ were calculated following the scheme proposed in Section 8.1 .4 of Saki et al. (2021) and starting from the existing literature (see Section 8.1.5 in Saki et al. 2021 and references therein).

\section{Discussion}

\section{Major element mass balance model}

The results of major-element mass balance model applied to the average protolith and leucosome compositions are presented in Table 3, where mathematically reliable solutions for the genesis of leucosomes $\left(\Sigma r^{2} 0.02-0.49\right.$; models A to D) are reported.

The model A $\left(\Sigma r^{2} 0.49\right)$ shows that the high- $\mathrm{SiO}_{2}(\approx 78$ wt $\%$ ) leucosome may be generated by $\approx 1 \%$ of partial melting of the gabbroic source with a residuum made up of $\mathrm{Pl}_{38} \mathrm{Hbl}_{49} \mathrm{Cpx}_{11}$. When $\mathrm{Bt}$ is included (model $\mathrm{B}, \Sigma r^{2} 0.43$ ), the major-element mass balance modelling shows a residuum of $\mathrm{Pl}_{37} \mathrm{Hbl}_{46} \mathrm{Cpx}_{12} \mathrm{Bt}_{2}$ and highlights in the matrix $\mathrm{c}$ the negligible role of the trioctahedral phyllosilicate with respect to the $\mathrm{Ca}-\mathrm{Al}$ minerals. When the Opx is added to the matrix $A$ (models $\mathrm{C}$ and $\mathrm{D}$ ), the mass balance modelling produces unrealistic results with invariably negative values in matrix $c$ (highlighted in red) for the Opx. These negative values are here interpreted as an excess or a non-involvement of this phase in the Mineral $=$ Protolith - Leucosome equation .

These results confirm the very low degree of partial melting calculated by Saki et al. (2021) and highlight an anatexis event dominated by Tschermak-bearing ( $\mathrm{Hbl}+\mathrm{Cpx})$ and anorthite-

Total iron as $\mathrm{Fe}_{2} \mathrm{O}_{3}$ 
Table 3 Major elements mass balance modelling

\section{b Liquid and mineral phases (matrix A)}

Model A

$\begin{array}{llllll} & \text { Av-Gb } & \text { Av-Lc } & P l-\# 7 & H b l-\# 4 & C p x-\# 2 \\ \mathrm{SiO}_{2} & 49.78 & 78.30 & 53.74 & 47.19 & 51.01 \\ \mathrm{TiO}_{2} & 1.10 & 0.07 & 0.02 & 1.47 & 1.11 \\ \mathrm{Al}_{2} \mathrm{O}_{3} & 16.07 & 13.02 & 30.41 & 7.92 & 5.06 \\ \mathrm{FeO}^{\mathrm{Tot}} & 7.62 & 0.54 & 0.03 & 14.11 & 6.02 \\ \mathrm{MnO} & 0.14 & 0.01 & 0.01 & 0.21 & 0.15 \\ \mathrm{MgO} & 8.01 & 0.23 & 0.00 & 13.27 & 15.34 \\ \mathrm{CaO} & 12.71 & 2.13 & 12.06 & 11.76 & 21.30 \\ \mathrm{Na} 2 \mathrm{O} & 2.26 & 4.09 & 4.58 & 1.16 & 0.46 \\ \mathrm{~K}_{2} \mathrm{O} & 0.84 & 0.66 & 0.07 & 0.37 & 0.00\end{array}$

Model B

$\begin{array}{lllllll} & \text { Av-Gb } & \text { Av-Lc } & \text { Pl-\#7 } & \text { Hbl-\#4 } & \text { Cpx-\#2 } & B t-\# 1 \\ \mathrm{SiO}_{2} & 49.78 & 78.30 & 53.74 & 47.19 & 51.01 & 37.07 \\ \mathrm{TiO}_{2} & 1.10 & 0.07 & 0.02 & 1.47 & 1.11 & 1.26 \\ \mathrm{Al}_{2} \mathrm{O}_{3} & 16.07 & 13.02 & 30.41 & 7.92 & 5.06 & 17.81 \\ \mathrm{FeO}^{\mathrm{Tot}} & 7.62 & 0.54 & 0.03 & 14.11 & 6.02 & 13.20 \\ \mathrm{MnO} & 0.14 & 0.01 & 0.01 & 0.21 & 0.15 & 0.04 \\ \mathrm{MgO} & 8.01 & 0.23 & 0.00 & 13.27 & 15.34 & 17.75 \\ \mathrm{CaO} & 12.71 & 2.13 & 12.06 & 11.76 & 21.30 & 0.04 \\ \mathrm{Na}_{2} \mathrm{O} & 2.26 & 4.09 & 4.58 & 1.16 & 0.46 & 0.40 \\ \mathrm{~K}_{2} \mathrm{O} & 0.84 & 0.66 & 0.07 & 0.37 & 0.00 & 8.78\end{array}$

Model C

$\begin{array}{lllllll} & \text { Av-Gb } & \text { Av-Lc } & P l-\# 7 & H b l-\# 4 & C p x-\# 2 & O p x-\# 3 \\ \mathrm{SiO}_{2} & 49.78 & 78.30 & 53.74 & 47.19 & 51.01 & 55.37 \\ \mathrm{TiO}_{2} & 1.10 & 0.07 & 0.02 & 1.47 & 1.11 & 0.02 \\ \mathrm{Al}_{2} \mathrm{O}_{3} & 16.07 & 13.02 & 30.41 & 7.92 & 5.06 & 0.36 \\ \mathrm{FeO}^{\mathrm{Tot}} & 7.62 & 0.54 & 0.03 & 14.11 & 6.02 & 22.18 \\ \mathrm{MnO} & 0.14 & 0.01 & 0.01 & 0.21 & 0.15 & 0.66 \\ \mathrm{MgO} & 8.01 & 0.23 & 0.00 & 13.27 & 15.34 & 21.13 \\ \mathrm{CaO} & 12.71 & 2.13 & 12.06 & 11.76 & 21.30 & 0.94 \\ \mathrm{Na} 2 \mathrm{O} & 2.26 & 4.09 & 4.58 & 1.16 & 0.46 & 0.04 \\ \mathrm{~K}_{2} \mathrm{O} & 0.84 & 0.66 & 0.07 & 0.37 & 0.00 & 0.00\end{array}$

Model D

\begin{tabular}{|c|c|c|c|c|c|c|c|c|c|c|c|c|c|}
\hline & $\mathrm{Av}-\mathrm{Gb}$ & Av-Lc & $\mathrm{Pl}$-\#7 & $H b l-\# 4$ & $C p x-\# 2$ & $B t-\# 1$ & $O p x-\# 3$ & & & & & & \\
\hline $\mathrm{SiO}_{2}$ & 49.78 & 78.30 & 53.74 & 47.19 & 51.01 & 37.07 & 55.37 & & 49.77 & 0.00 & $\mathrm{Av}-\mathrm{Lc}$ & 0.065 & $=F$ \\
\hline $\mathrm{TiO}_{2}$ & 1.10 & 0.07 & 0.02 & 1.47 & 1.11 & 1.26 & 0.02 & & 1.14 & -0.04 & $P l$ l\#7 & 0.283 & $30.1 \%$ \\
\hline $\mathrm{Al}_{2} \mathrm{O}_{3}$ & 16.07 & 13.02 & 30.41 & 7.92 & 5.06 & 17.81 & 0.36 & & 16.06 & 0.01 & $H b l-\# 4$ & 0.668 & $71.1 \%$ \\
\hline $\mathrm{FeO}^{\mathrm{Tot}}$ & 7.62 & 0.54 & 0.03 & 14.11 & 6.02 & 13.20 & 22.18 & & 7.60 & 0.01 & $C p x-\# 2$ & 0.067 & $7.1 \%$ \\
\hline $\mathrm{MnO}$ & 0.14 & 0.01 & 0.01 & 0.21 & 0.15 & 0.04 & 0.66 & & 0.07 & 0.07 & $B t-\# 1$ & 0.058 & $6.2 \%$ \\
\hline $\mathrm{MgO}$ & 8.01 & 0.23 & 0.00 & 13.27 & 15.34 & 17.75 & 21.13 & & 8.04 & -0.03 & $O p x-\# 3$ & -0.137 & $-14.6 \%$ \\
\hline $\mathrm{CaO}$ & 12.71 & 2.13 & 12.06 & 11.76 & 21.30 & 0.04 & 0.94 & & 12.70 & 0.01 & Sum & 1.00 & \\
\hline $\mathrm{Na}_{2} \mathrm{O}$ & 2.26 & 4.09 & 4.58 & 1.16 & 0.46 & 0.40 & 0.04 & & 2.38 & -0.12 & & & \\
\hline $\mathrm{K}_{2} \mathrm{O}$ & 0.84 & 0.66 & 0.07 & 0.37 & 0.00 & 8.78 & 0.00 & & 0.82 & 0.02 & & & \\
\hline & & & & & & & & Sum & 98.59 & 0.02 & $=\Sigma r^{2}$ & & \\
\hline
\end{tabular}

$\mathbf{b}^{\prime} \quad \mathbf{b}^{-b^{\prime}} \quad$ c

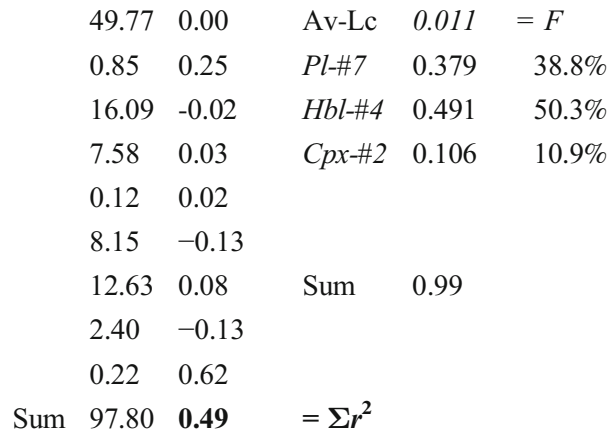

\begin{tabular}{|c|c|c|c|c|}
\hline 49.77 & 0.01 & $\mathrm{Av}-\mathrm{Lc}$ & 0.014 & $=F$ \\
\hline 0.84 & 0.25 & $\mathrm{Pl}$-\#7 & 0.374 & $38.4 \%$ \\
\hline 16.13 & -0.06 & $H b l-\# 4$ & 0.462 & $47.4 \%$ \\
\hline 7.50 & 0.12 & $C p x-\# 2$ & 0.121 & $12.4 \%$ \\
\hline 0.12 & 0.02 & $B t-\# 1$ & 0.018 & $1.9 \%$ \\
\hline 8.30 & -0.29 & & & \\
\hline 12.54 & 0.16 & Sum & 0.99 & \\
\hline 2.37 & -0.10 & & & \\
\hline 0.36 & 0.48 & & & \\
\hline 97.94 & 0.43 & $=\Sigma r^{2}$ & & \\
\hline
\end{tabular}

$\begin{array}{llllr}49.78 & 0.00 & \text { Av-Lc } & 0.026 & =F \\ 0.96 & 0.14 & P l-\# 7 & 0.351 & 36.3 \% \\ 16.02 & 0.05 & H b l-\# 4 & 0.588 & 60.9 \% \\ 7.69 & -0.07 & C p x-\# 2 & 0.075 & 7.8 \% \\ 0.11 & 0.03 & \text { Opx-\#3 } & -0.049 & -5.1 \% \\ 7.93 & 0.08 & & & \\ 12.75 & -0.05 & \text { Sum } & 0.99 & \\ 2.43 & -0.16 & & & \\ 0.26 & 0.58 & & & \\ 97.92 & \mathbf{0 . 4 0} & =\Sigma \boldsymbol{r}^{2} & & \end{array}$


bearing $(\mathrm{Pl})$ phases. Furthermore, the higher number of rock samples considered in the model permits to refine the amount of each phase involved in the batch melting event, confirming a scenario (Fig. 2c) of amphibole-dominated dehydration melting (e.g., Beard and Lofgren 1991) to generate the studied in situ trondhjemites.

\section{Trace and REE element EBM models}

Based on the previously presented major-element mass balance modelling, and consistency with the work of Saki et al. (2021), we applied EBM modelling (Eq. 2) to Y vs. Sr/Y and $\mathrm{Yb}$ vs. Dy/Yb compositional systems. Considering the reacting assemblage $\mathrm{Pl}_{38} \mathrm{Hbl}_{49} \mathrm{Cpx}_{11}$, we calculated the mineral/melt and the bulk mineral/melt partition coefficients. Results are presented in Table 4. The average trondhjemite (Av-Lc with $\approx 193$ ppm Sr, $\approx 9$ ppm Y, $\approx 1.3$ ppm Dy, and $\approx 0.9 \mathrm{ppm} \mathrm{Yb}$ ) corresponds to $\approx 1-5 \%$ of batch melting (Fig. $3(\mathrm{a}, \mathrm{b})$ ) of the average Hbl-gabbro protolith (Av-Gb with $\mathrm{Sr}$ $\approx 486, \mathrm{Y} \approx 15, \mathrm{Dy} \approx 2.8$, and $\mathrm{Yb} \approx 1.4$ ). However, the studied trondhjemite samples show a wide distribution with respect to the average composition in plots of Y vs. Sr/Y (Fig. 3(a)) and $\mathrm{Yb}$ vs. Dy/Yb (Fig. 3(b)). We therefore decided to explore the role of each mineral phase involved through the effect of their mineral/melt partition coefficients. From calculated partition coefficients in Table 4, it is possible to observe how $\mathrm{Sr}$ is mainly controlled by the plagioclase. An increase of the anorthite-plagioclase effect $\left({ }^{P l} D_{S r}\right.$ up to 1.21) is capable to describe leucosomes with low $\mathrm{Sr} / \mathrm{Y}$ ratio (Fig. 2c), whereas higher involvement of Tschermak-bearing inosilicates $(\mathrm{Hbl+}$ ${ }^{C p x} D_{Y}$ up to 1.068 , with $\left.{ }^{H b l} D_{Y:}{ }^{C p x} D_{Y}=3: 1\right)$ controlling $\mathrm{Y}$ is capable to better approximate melts with higher $\mathrm{Sr} / \mathrm{Y}$ ratio (Fig. 2d) with respect to the average composition. However, only when the two effects are coupled is it possible to fully describe the leucosomes in the Sr-Y system.

A less significant role for plagioclase is instead observed when approaching the Dy-Yb system (Table 4), where the selected HREE elements are mostly controlled by the $\mathrm{Ca}-\mathrm{Al}$ inosilicates. In particular, Dy is nearly to be totally controlled by $\mathrm{Hbl}$, whereas a ${ }^{H b l} D_{Y b}:{ }^{C p x} D_{Y b}=3: 1$ relationship exists for $\mathrm{Yb}$, comparable to that previously observed for $\mathrm{Y}$. While

\begin{tabular}{llllll}
$\begin{array}{l}\text { Table 4 Calculated } \\
\text { partition coefficients } \\
\text { used in the EBM } \\
\text { modelling }\end{array}$ & \multicolumn{5}{l}{$\begin{array}{l}\text { Calculated mineral/melt partition } \\
\text { coefficients }\end{array}$} \\
\cline { 2 - 6 } & & $\mathrm{Pl}$ & $\mathrm{Hbl}$ & $\mathrm{Cpx}$ & $\mathrm{Bulk}$ \\
\hline & $\mathrm{D}_{\mathrm{Sr}}$ & 0.858 & 0.272 & 0.068 & 1.198 \\
& $\mathrm{D}_{\mathrm{Y}}$ & 0.092 & 0.769 & 0.254 & 1.115 \\
& $\mathrm{D}_{\mathrm{Dy}}$ & 0.033 & 1.043 & 0.097 & 1.173 \\
& $\mathrm{D}_{\mathrm{Yb}}$ & 0.132 & 0.725 & 0.218 & 1.074 \\
\hline & & & & &
\end{tabular}

calculated variations of the bulk $D_{D y}$ are not capable to describe the leucosome chemistry (Fig. 2f), opposite a minimum variability of the ${ }^{H b l+C p x} D_{Y b}(0.908-0.998)$ is effective in describing near all the leucosomes (Fig. 2g). Again, only when the minor effect of $D_{D y}$ is coupled with $D_{Y b}$ is the whole dataset of trondhjemites described. Clinopyroxene and hornblende show similar effects in controlling the selected trace and REE elements during the partial melting event; however, the relation ${ }^{C p x} D<<{ }^{H b l} D$ is observed, suggesting that only $\mathrm{Pl}+$ $\mathrm{Hbl}$ played a main role during this incipient anatexis.

\section{Classic and forward modelling thermobarometry: the path to anatexis}

To assess the pressure-temperature (P-T) conditions of genesis of $\mathrm{CG}$ trondhjemite leucosomes, we integrate here (i) classic thermobarometry as derived from the Zircon-saturation thermometry $\left(\mathrm{T}_{\mathrm{Zr}}\right.$, Watson and Harrison 1983) and the Monazitesolubility model ( $\mathrm{T}_{\mathrm{REE}}$, Montel 1993) and (ii) forward modelling thermobarometry through the pseudosections method. Results are then discussed also considering the previous results obtained by Saki et al. (2020, 2021).

The zircon-saturation model provides information on saturation condition of zircon within an hydrous felsic Alsaturated magma (Watson and Harrison 1983) and therefore provides a minimum estimate for magma temperature prior to the extensive crystallization and cooling (e.g., Miller et al. 2003; Lucci et al. 2018). The trondhjemite leucosomes show values of $\mathrm{Zr}$ in the range $34-124 \mathrm{ppm}$, corresponding to $\mathrm{T}_{\mathrm{Zr}}=$ 684-694 $\pm 25^{\circ} \mathrm{C}$ (Table 1) and to a weighted mean value of $723 \pm 13{ }^{\circ} \mathrm{C}( \pm 1 \mathrm{~s}$ standard deviation of the weighted mean, MSWD $=0.98, n=14)$. The monazite-solubility model (Montel 1993) is based on the effect of LREE content in Capoor felsic melt and operated assuming the whole-rock composition as representative of a frozen liquid. The solubility LREE temperatures were calculated for variable water content $\left(0.1-6.0 \mathrm{wt} \% \mathrm{H}_{2} \mathrm{O}\right)$; results are reported in Table 1. These two models show convergence $\left(\mathrm{T}_{\mathrm{REE}}=\mathrm{T}_{\mathrm{Zr}} \pm 20^{\circ} \mathrm{C}\right)$ at (i) $733 \pm 19$ ${ }^{\circ} \mathrm{C}$ (MSWD 0.58, $\left.n=7\right)$ for anhydrous conditions $\left(\mathrm{H}_{2} \mathrm{O} 0.1\right.$ wt\%) in samples GH-L2, GH-L4, GH-L5, GH-Mig4, GHMig5, GH-Mig8, and CG-Lu1 and (ii) $710 \pm 19{ }^{\circ} \mathrm{C}$ (MSWD $0.22, n=7)$ for hydrous conditions $\left(1-6 \mathrm{wt} \% \mathrm{H}_{2} \mathrm{O}\right)$ in samples GH-L1, GH-L3, GH-Mig6, CG-Lu2, CG-Lu3, CG-Lu4, and CG-Lu5. When these two clusters are merged, the obtained weighted mean $\mathrm{T}_{\mathrm{REE}}\left(722 \pm 13{ }^{\circ} \mathrm{C}\right.$, MSWD $\left.=0.60, n=14\right)$ overlaps that from zircon-saturation model. In agreement with the existing literature on $\mathrm{SiO}_{2}$-rich felsic melts (e.g., Miller et al. 2003; Rossetti et al. 2013; Lucci et al. 2018), the convergence of these two models could represent the temperature at the onset of crystallization, also resembling the temperature of the anatectic source (e.g., Rossetti et al. 2013).

To refine the thermobaric conditions leading to the Hblgabbro anatexis and trondhjemite melt production in 
Cheshmeh-Ghasaban area, we used the average protolith AvGb composition for forward modelling thermobarometry using the software Perple_X 6.9.0 (Connolly 2005; downloaded June 21, 2020, http://www.perplex.ethz.ch). The model system NCKFMASHT $\left(\mathrm{Na}_{2} \mathrm{O}-\mathrm{CaO}-\mathrm{K}_{2} \mathrm{O}-\right.$ $\mathrm{FeO} *-\mathrm{MgO}-\mathrm{Al}_{2} \mathrm{O}_{3}-\mathrm{SiO}_{2}-\mathrm{H}_{2} \mathrm{O}-\mathrm{TiO}_{2}$ ) was chosen assuming the total iron as $\mathrm{FeO}$ due to the presence of ilmenite in the preserved primary mineral assemblage and lack of any secondary $\mathrm{Fe}^{3+}$-bearing phases. Three forward models were developed: the main one and two testbeds to verify its reliability on identifying the melt-in conditions. Concerning the main model (hereafter "model A"), the solid-solution models selected are "Augite $(G)$ " for clinopyroxene (Green et al. 2016), "Opx(W)" for orthopyroxene (White et al. 2014), "Amph (DPW)" for Ca-hornblende (Dale et al. 2005) , "Bio (TCC)" for biotite (Tajcmanova et al. 2009), "feldspar" for feldspar (Fuhrman and Lindsley 1988), and "melt(G)" for melt (Green et al. 2016). The analyzed loss on ignition (LOI) was assumed as $\mathrm{H}_{2} \mathrm{O}$ content, coherently with the existing literature on partial melting modelling (e.g., Rossetti et al. 2020; Saki et al. 2021). The ilmenite (Ilm) end-member is also used in the calculation. The first testbed (hereafter "model T1") was developed using the same solid-solution models of model A but considering water-present conditions $\left(\mathrm{H}_{2} \mathrm{O}\right.$ in excess). The second testbed (hereafter "model T2") was developed using LOI as $\mathrm{H}_{2} \mathrm{O}$ content but a different set of solidsolution models: "melt $(\mathrm{G})$ " for melt (Green et al. 2016), "Augite $(G)$ " for clinopyroxene (Green et al. 2016), cAmph(G) for Ca-hornblende (Green et al. 2016), Pl(I1,HP) and $\mathrm{Fsp}(\mathrm{C} 1)$ for ternary feldspar (Holland and Powell 2003), $\mathrm{Bi}(\mathrm{W})$ for biotite (White et al. 2014), Opx (W) for orthopyroxene (White et al. 2014), and Ilm (WPH) for
Fig. 4 Forward modelling thermobarometry: model A. a Representative P-T pseudosection calculated for the Av-Gb average Hbl-gabbro protolith in the system NCKFMASHT $\left(\mathrm{Na}_{2} \mathrm{O}\right.$ $\mathrm{CaO}-\mathrm{K}_{2} \mathrm{O}-\mathrm{FeO} *-\mathrm{MgO}-\mathrm{Al}_{2} \mathrm{O}_{3}-$ $\mathrm{SiO}_{2}-\mathrm{H}_{2} \mathrm{O}-\mathrm{TiO}_{2}$ ) with LOI as $\mathrm{H}_{2} \mathrm{O}$ wt\% using the Perple $\mathrm{X}$ software. b Isopleths derived from the calculated pseudosections and indicating the calculated amount of generated melt (wt\%). c Temperaturepressure-melt (wt\%) representation of the progressive amount of melt generated through the partial melting of the average Av-Gb Hbl-gabbro protolith
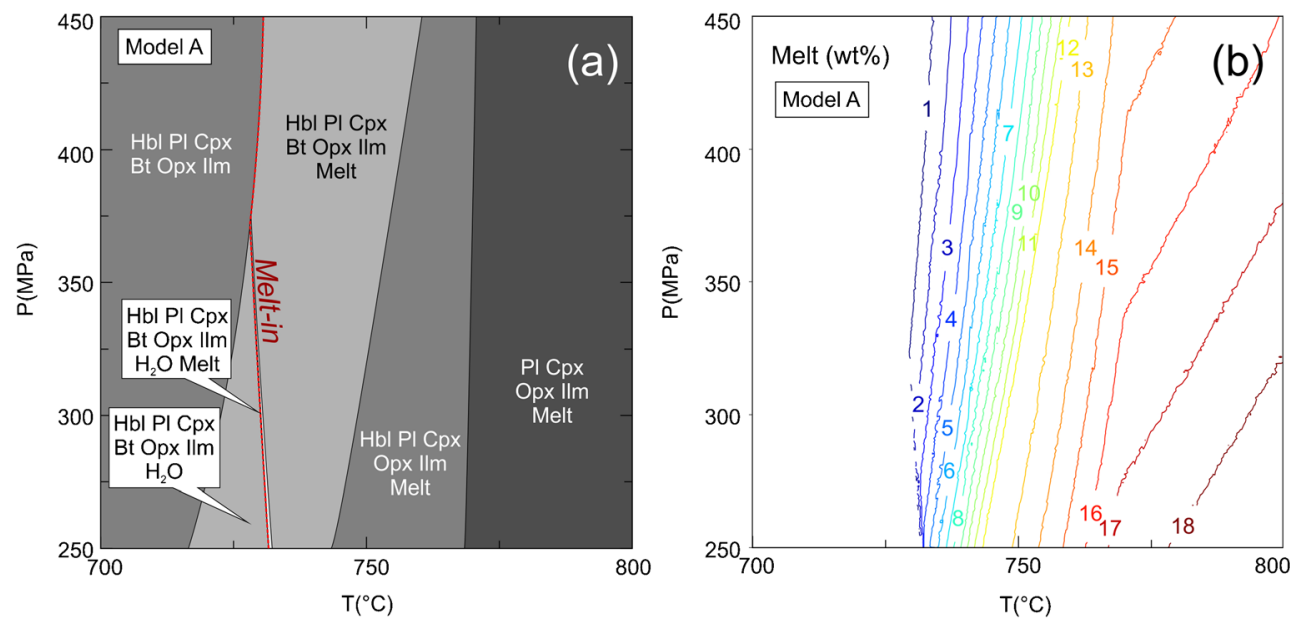

(c)

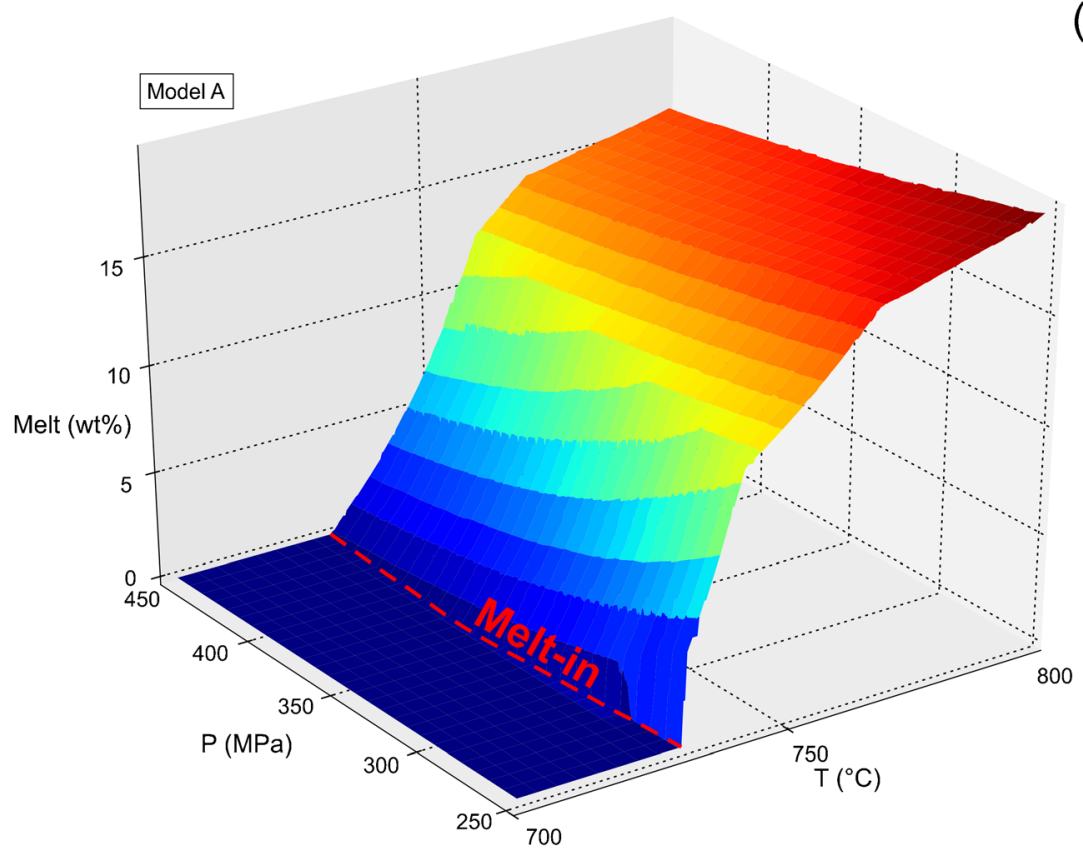


ilmenite (White et al. 2014). Further details are in the solution. dat file enclosed in the Perple X package, whereas the reference database is the hp62ver.dat file, an update version of the Holland and Powell (2011) thermodynamic dataset. The single-phase volume isopleths (melt, $\mathrm{Pl}, \mathrm{Hbl}, \mathrm{Cpx}, \mathrm{Opx}, \mathrm{Bt}$ ) and the mineral composition isopleths (i.e., an in plagioclase) were drawn by PyWerami (version 2.0.1, downloaded from the website http://petrol.natur.cuni.cz/ ondro/pywerami: home). The melt and mineral phases involved were expressed in weight $\%(\mathrm{wt} \%)$ and were in accordance with the results from the EBM models. Starting from the work of Saki et al. (2021), the pseudosections were constructed from 700 to $800^{\circ} \mathrm{C}$ and between 250 and $450 \mathrm{MPa}$. The results of forward modelling thermobarometry are shown in Figs. 4, 5, 6 , and 7. The representative and simplified model A pseudosection calculated for the bulk chemistry of the Av$\mathrm{Gb}$ average protolith is presented in Fig. 4 a, where the melt appearance (red dashed curve) is constrained at $\approx 725-730^{\circ} \mathrm{C}$. The melt and mineral phase isopleths (wt $\%)$ as derived from the pseudosections calculation are used to investigate the evolution of the partial melting evolution and are presented in Figs. $4 \mathrm{a}$ and $\mathrm{b}$ and 5. In particular, the melt isopleths (wt\%) are here used as a proxy of the anatexis. A three-dimensional temperature-pressure-melt abundances (T-P-melt) diagram (Fig. 4c) is also proposed to better visualize the melt appearance (melt-in curve) in the system and its progressive production at higher temperatures. Replicate testbeds models $\mathrm{T} 1$ and T2 for water-saturated conditions (Fig. 5a, b) and different solid-solution models (Fig. 5c, d), respectively, show melt generation at $\approx 720-730^{\circ} \mathrm{C}$ comparable to the main model $\mathrm{A}$ (Fig. 4). However, with respect to main model A, the two testbed models fail in accurately reproducing the $\mathrm{CG}$ metatexite. The model $\mathrm{T} 1$ with $\mathrm{H}_{2} \mathrm{O}$ in excess (Fig. 5a) is characterized by a very high melt-production rate (Fig. 5b) in contrast with the observed low volume of in situ leucosomes. Opposite, the model T2 based on a different set of solution models (Fig. 5b) shows a reasonable low meltproduction rate (Fig. 5d) but fails in correctly reproducing the primary assemblage of the Hbl-gabbro as shown by the lack of primary orthopyroxene in the pre-melting protolith. Consequently, the main model A represents the best forward modelling thermobarometry approximation of the anatexis of the CG Hbl-gabbro to generate the in situ trondhjemite leucosomes.

How did the protolith-forming $\mathrm{Pl}+\mathrm{Hbl}+\mathrm{Cpx}+\mathrm{Bt}+\mathrm{Opx}$ primary assemblage participate to the partial melting event? The
Fig. 5 Forward modelling thermobarometry: testbeds models T1 and T2. a Model T1: representative $\mathrm{P}-\mathrm{T}$ pseudosection calculated for the Av-Gb average Hbl-gabbro protolith in the system NCKFMASHT $\left(\mathrm{Na}_{2} \mathrm{O}-\right.$ $\mathrm{CaO}-\mathrm{K}_{2} \mathrm{O}-\mathrm{FeO} *-\mathrm{MgO}-\mathrm{Al}_{2} \mathrm{O}_{3}-$ $\mathrm{SiO}_{2}-\mathrm{H}_{2} \mathrm{O}-\mathrm{TiO}_{2}$ ) with waterexcess conditions and solidsolution models equal to "model A" using the Perple_X software. b Model T1: isopleths derived from the calculated pseudosections and indicating the calculated amount of generated melt (wt\%). c Model T2: representative P-T pseudosection calculated for the Av-Gb average Hbl-gabbro protolith in the system NCKFMASHT $\left(\mathrm{Na}_{2} \mathrm{O}\right.$ $\mathrm{CaO}-\mathrm{K}_{2} \mathrm{O}-\mathrm{FeO} *-\mathrm{MgO}-\mathrm{Al}_{2} \mathrm{O}_{3}-$ $\mathrm{SiO}_{2}-\mathrm{H}_{2} \mathrm{O}-\mathrm{TiO}_{2}$ ) with LOI as $\mathrm{H}_{2} \mathrm{O}$ wt $\%$ and a different set of solid-solution models (see text for further details) using the Perple X software. d Model T2: isopleths derived from the calculated pseudosections and indicating the calculated amount of generated melt (wt\%)
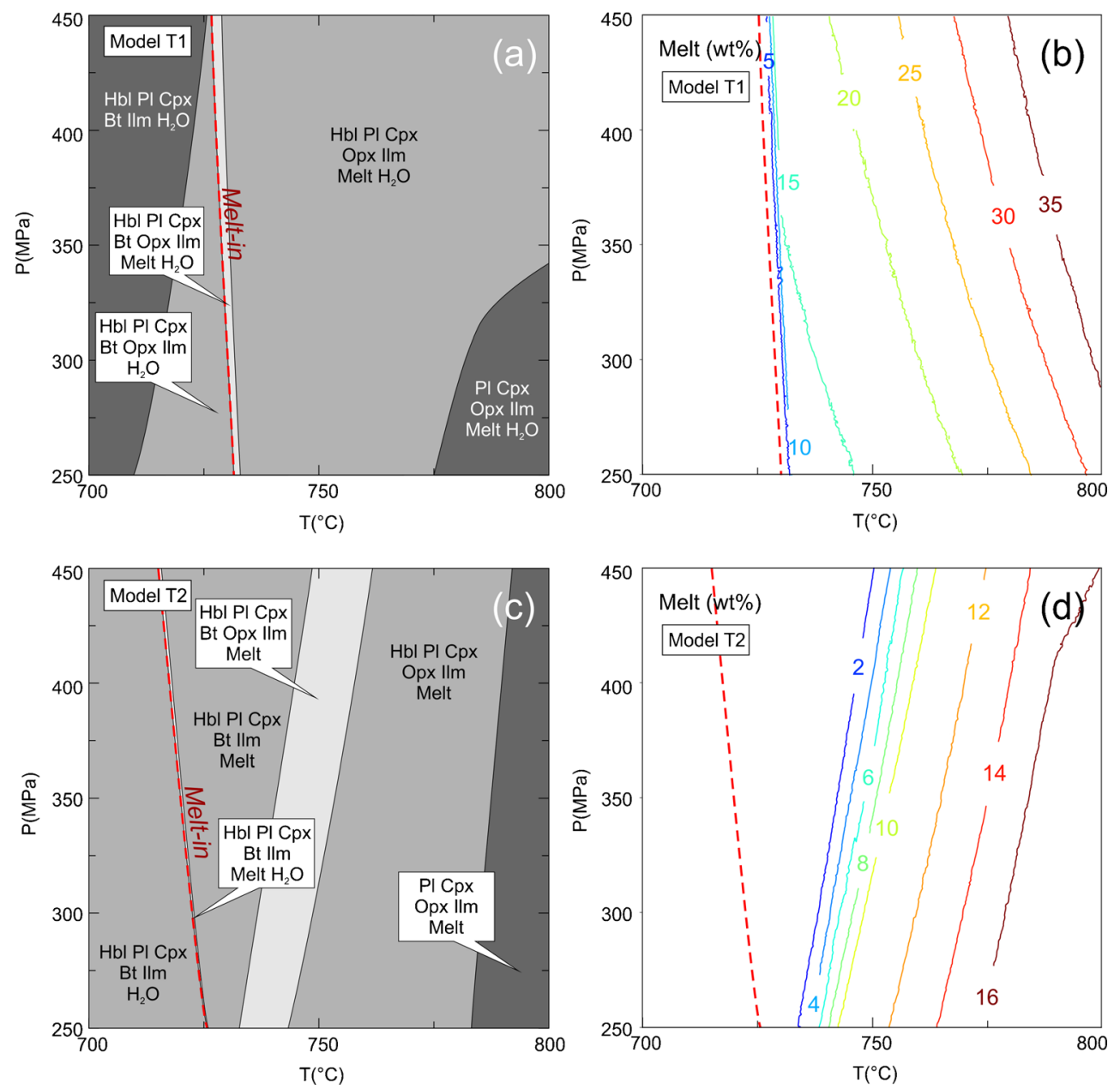
Fig. 6 Forward modelling thermobarometry. Model A: isopleths derived from the calculated pseudosections: a plagioclase (wt \%), b anorthite (XAn) in plagioclase, $\mathbf{c}$ hornblende (wt\%), d augitic-

clinopyroxene (wt\%), e biotite (wt $\%$ ), and $\mathbf{f}$ orthopyroxene (wt\%)
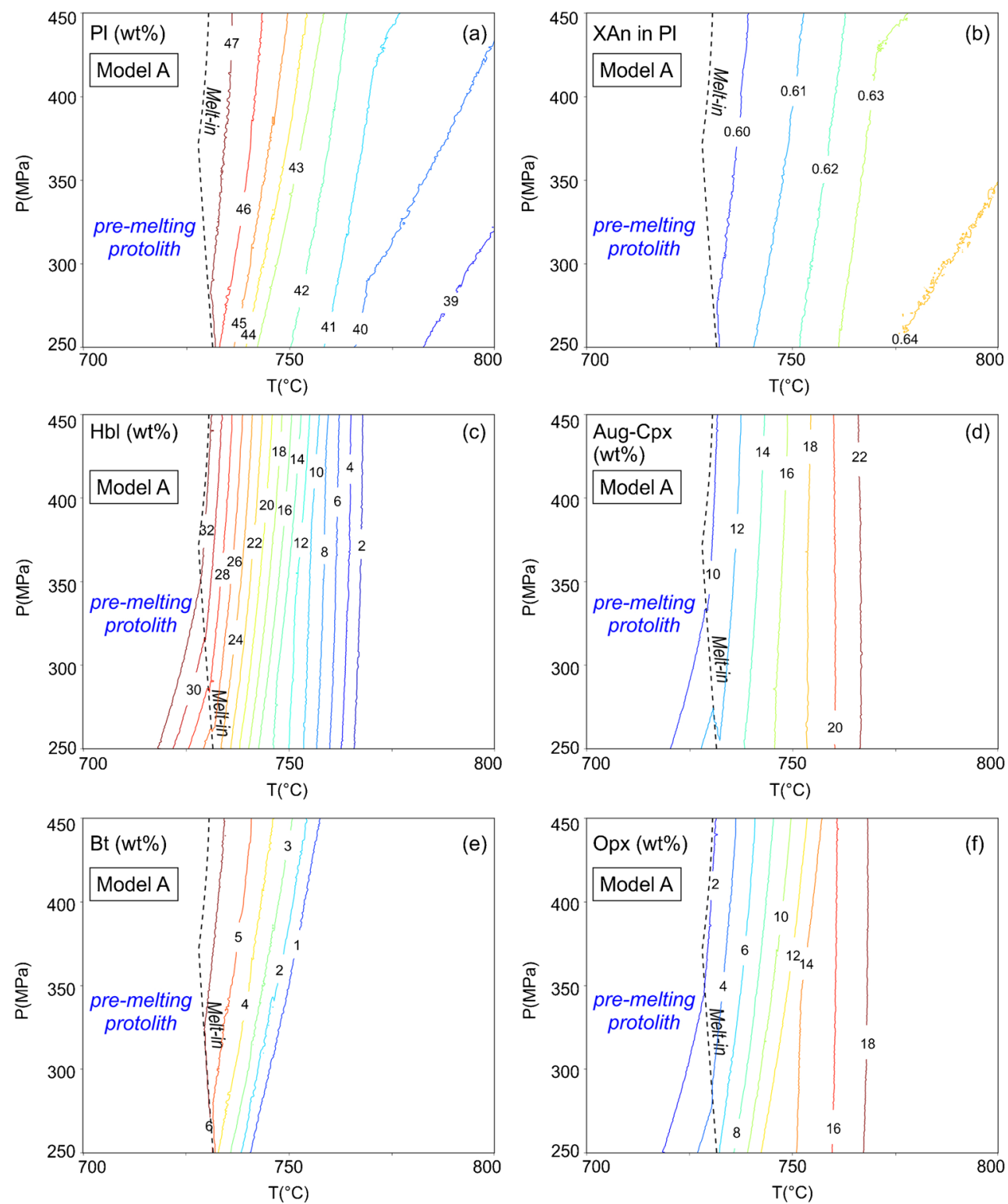

possible solution to this point is explored hereafter using mineral volume and mineral composition isopleths as calculated for the main model A (Fig. 5).

The pseudosection method indicates that the protolith prior to melting ("pre-melting protolith" field in diagrams of Fig. $6 \mathrm{a}-\mathrm{f}$ ) is characterized by the following assemblage $\mathrm{Pl}_{47} \mathrm{Hbl}_{26}$ ${ }_{32} \mathrm{Cpx}_{10-12} \mathrm{Bt}_{6} \mathrm{Opx}_{2-6}$, very close to that determined by petrographic observations ( $\mathrm{P}_{40-50} \mathrm{Hbl}_{30-35} \mathrm{Cpx}_{10-}$ $\left.{ }_{20} \mathrm{Bt}_{<10} \mathrm{Opx}_{<5} \mathrm{Qz}_{<5}\right)$. Furthermore, the predicted anorthite component $(\mathrm{X}-\mathrm{An}=0.60)$ in plagioclase fully overlaps the observed one $(\mathrm{X}-\mathrm{An}=0.57-0.60)$. When the protolith starts to melt $\left(\mathrm{T}>725^{\circ} \mathrm{C}\right)$, the following conditions are observed: (i) the amount of plagioclase progressively decreases (Fig. 6a), (ii) the plagioclase is characterized by a progressive increase of the anorthite compound (Fig. 6b), (iii) the amount of hornblende (Fig. 6c) and biotite (Fig. 6e) progressively decrease, and (iv) the amount of pyroxenes $(\mathrm{Cpx}+\mathrm{Opx})$ progressively increase together with melt production. These trends can be interpreted as a batch melting event (i) developed at the expenses of the $\mathrm{Pl}+\mathrm{Hbl}+\mathrm{Bt}$ assemblage and (ii) associated to the growth of newly formed $\mathrm{Cpx}+\mathrm{Opx}$. These two conditions are compatible with well-known reactions published in literature (e.g., Rushmer 1991; Pattison 1991; Thompson and Ellis 1994; Graphchikov et al. 1999; Weinberg and Hasalová 2015) and qualitatively discussed by Saki et al. (2020) for the studied mafic migmatites:

$$
\begin{aligned}
& \mathrm{Hbl}+\mathrm{Pl}=\mathrm{Opx}+\mathrm{Cpx}+\text { melt } \\
& \mathrm{Hbl}+\mathrm{Qz}+\mathrm{H} 2 \mathrm{O}=\mathrm{Cpx}+\mathrm{Opx}+\text { melt } \\
& \mathrm{Bt}+\mathrm{Qz}=\mathrm{Opx}+\text { melt }
\end{aligned}
$$




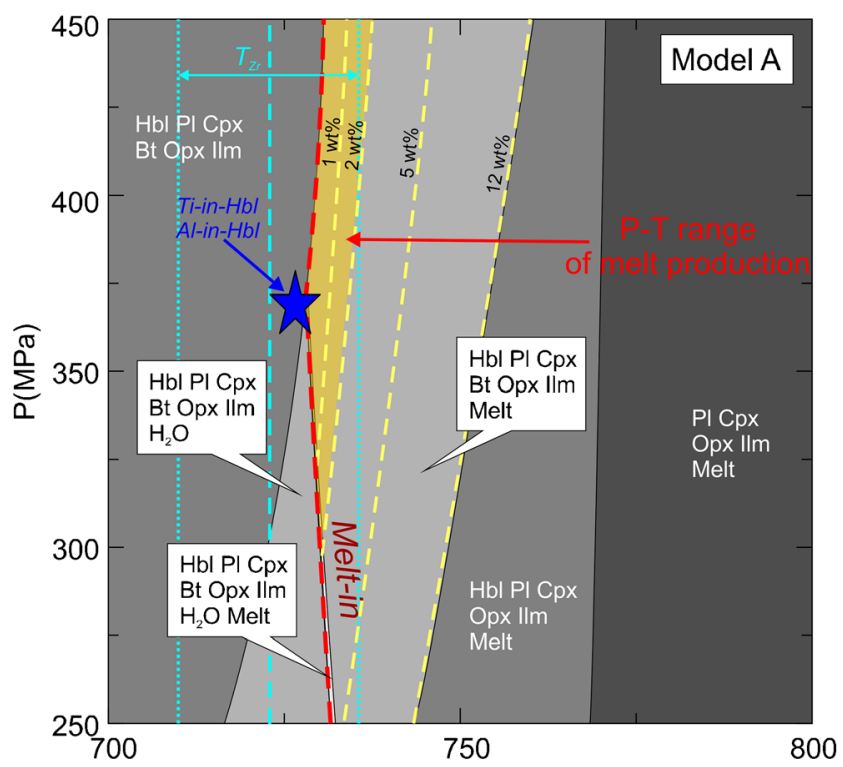

Fig. 7 Classic and forward modelling thermobarometry. The representative model A pseudosection presented in Fig. 4 a is integrated with its selected melt (wt \%) isopleths and zircon-saturation thermometry $\left(\mathrm{T}_{\mathrm{Zr}}\right)$ weighted mean value (cyan dashed line) and 1s range (cyan dotted field) calculated for trondhjemite samples. The blue star represents Ti-in$\mathrm{Hbl}$ thermometry and Al-in-Hbl barometry estimates from Saki et al. (2021). The pressure-temperature (P-T) genetic domain of CheshmehGhasaban trondhjemites is indicated with the yellow shaded area. Mineral abbreviations follow Whitney and Evans (2010)

The refined major-trace-REE EBM modelling and the study of partition coefficients proposed in this work indicate that in situ trondhjemite leucosome corresponds to a very low degree $(\approx 1-2 \%)$ of partial melting of the Hbl-protolith mainly controlled by $\mathrm{Ca}-\mathrm{Al}$-bearing phases such as hornblende and plagioclase, whereas the improved thermometry estimates based on the zircon-saturation and monazite-solubility models indicated that the melting event was developed at $\approx 720-730$ ${ }^{\circ} \mathrm{C}$. Saki et al. (2021), through classic barometry modelling applied to hornblende in the mesosome, propose a pressure estimates of $360 \pm 60 \mathrm{MPa}$ for the partial melting. Integrating these results with those obtained from the forward modelling thermobarometry model A (Fig. 7), it is possible to derive the following conclusions: (i) the anatexis responsible for the trondhjemite leucosome production is an incipient partial melting event developed close to the solidus at a relatively low temperature $\left(<750^{\circ} \mathrm{C}\right)$, (ii) the appearance of new generation of pyroxenes $(\mathrm{Cpx}+\mathrm{Opx})$ is accompanying the melt production since the very early stage, and (iii) the trioctahedral mica is not involved in the melting reactions for a very low degree $(<2 \%)$ of partial melting and therefore reaction of Eq. (5) can be discarded. Concerning the latter point, when trondhjemite leucosome chemistry are plotted in a $\mathrm{Na}_{2} \mathrm{O}$ CaO- $\mathrm{K}_{2} \mathrm{O}$ diagram (Fig. 2c), they fall close to the $\mathrm{Na}_{2} \mathrm{O}-$ $\mathrm{CaO}$ axis, within the field of experimental melts derived from low pressure $(P<500 \mathrm{MPa})$ amphibole-dominated dehydration processes in amphibole-bearing mafic rocks, whereas a biotite participation would have led to melts with higher $\mathrm{K}_{2} \mathrm{O}$ contents (e.g., Gao et al. 2016 and references therein). The noninvolvement of biotite in the dehydration melting process is also supported by its preserved texture when approaching the in situ leucosomes. This is also in line with the existing literature (e.g., Patiño Douce and Beard 1995; Singh and Johannes 1996) where it has been demonstrated for $P<500 \mathrm{MPa}$ that (i) biotite can persist to higher temperatures than hornblende and (ii) a biotite-plagioclase assemblage starts to melt at 750 $770^{\circ} \mathrm{C}$, a temperature slightly higher than that obtained for CG trondhjemite leucosomes.

In the work of Saki et al. (2021), it was proposed a comparison between the chemistry of the CG trondhjemite leucosomes and that of experimental melts produced at $850-1100^{\circ} \mathrm{C}$ for $\mathrm{P} 100-500 \mathrm{MPa}$ conditions by partial melting of amphibole-bearing source rocks (e.g., Beard and Lofgren 1991; Sisson and Grove 1993; Patiño Douce and Beard 1995; Springer and Seck 1997; López and Castro 2001; Gao et al. 2016). Following their approach and using $\mathrm{SiO}_{2}$ content as differentiation index, through the application of the "Color Fill Contour" tool in OriginPro 8.5.0 software, we derived the isolines (dashed black lines in Fig. 8) for the $900^{\circ} \mathrm{C}$ and the $1000^{\circ} \mathrm{C}$ experimental melting temperatures, for all the major elements. A decrease in melting temperature corresponds to experimental melts (grey circles in Fig. 8) characterized by a progressive $\mathrm{SiO}_{2}$ (wt\%) content increase associated with an opposite decrease of $\mathrm{Al}_{2} \mathrm{O}_{3}, \mathrm{TiO}_{2}, \mathrm{MgO}, \mathrm{FeO}^{\text {tot }}, \mathrm{MnO}, \mathrm{CaO}$, and $\mathrm{P}_{2} \mathrm{O}_{5}$ (wt\%) contents. No clear relationship is highlighted for $\mathrm{Na}_{2} \mathrm{O}$ and $\mathrm{K}_{2} \mathrm{O}$ contents. As explained by Sisson et al. (2005), experimental runs close to the solidus and for $T<800^{\circ} \mathrm{C}$ are usually not attempted because of the very small volumes of melt produced precluding trustworthy bulk analyses. However, observing the Harker diagrams of Fig. 8, it would be expected that melt generated at such low temperatures would present still higher $\mathrm{SiO}_{2}$ content and even lower $\mathrm{Al}_{2} \mathrm{O}_{3}, \mathrm{TiO}_{2}$, $\mathrm{MgO}, \mathrm{FeO}^{\text {tot }}, \mathrm{MnO}, \mathrm{CaO}$, and $\mathrm{P}_{2} \mathrm{O}_{5}$ contents. When $\mathrm{CG}$ trondhjemites are plotted in Harker diagram of Fig. 8, they completely match the expected compositional characteristics for low $\mathrm{T}$ and low $\mathrm{P}$ melts derived by amphibole-dominated dehydration melting from a mafic protolith. Furthermore, their integration in these Harker diagrams permit also to graphically trace the $800^{\circ} \mathrm{C}$ isoline (red dashed lines) contributing to our knowledge on low-pressure amphibole-dominated incipient anatectic events affecting amphibole-bearing sources, and furthermore to the genesis of high- $\mathrm{SiO}_{2}$ $(>70 \mathrm{wt} \%)$ low $-\mathrm{Al}_{2} \mathrm{O}_{3}(<15 \mathrm{wt} \%)$ trondhjemites (sensu Barker and Arth 1976). 

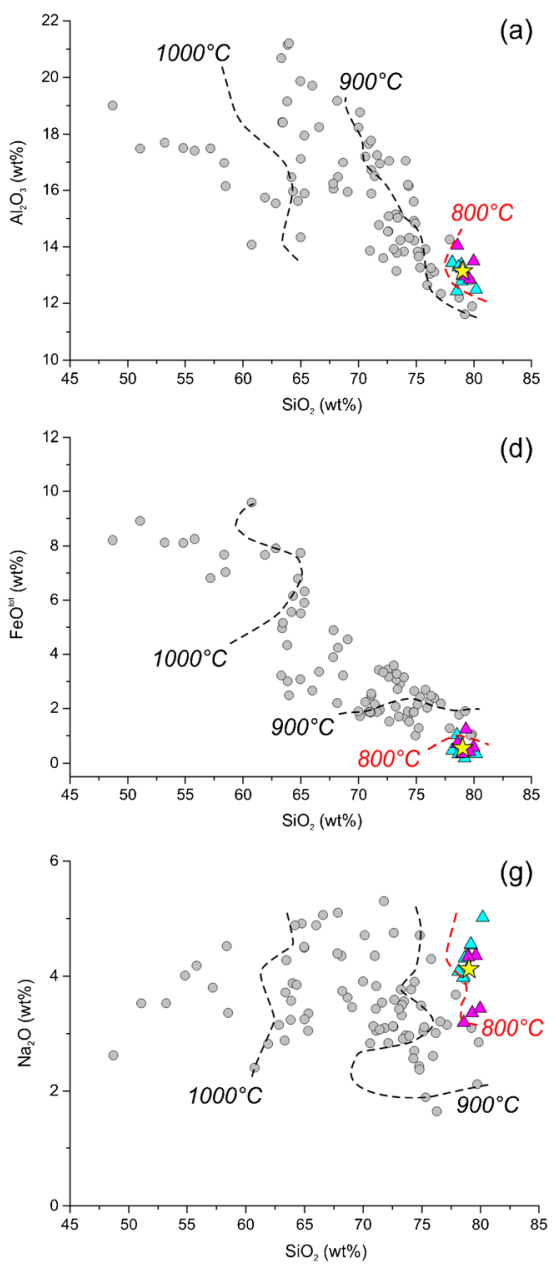

(g)

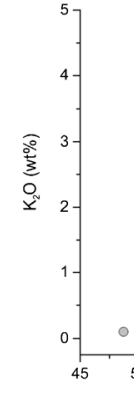

Fig. 8 Harker diagrams showing the comparison between CheshmehGhasaban trondhjemites and experimental melts from low pressure $(<$ $500 \mathrm{MPa}$ ) amphibole-dehydration melting of mafic sources. Dashed black lines represent the $900^{\circ}$ and $1000^{\circ} \mathrm{C}$ experimental melting temperatures, whereas the red dashed lines are the $800^{\circ} \mathrm{C}$ isolines obtained from (b)
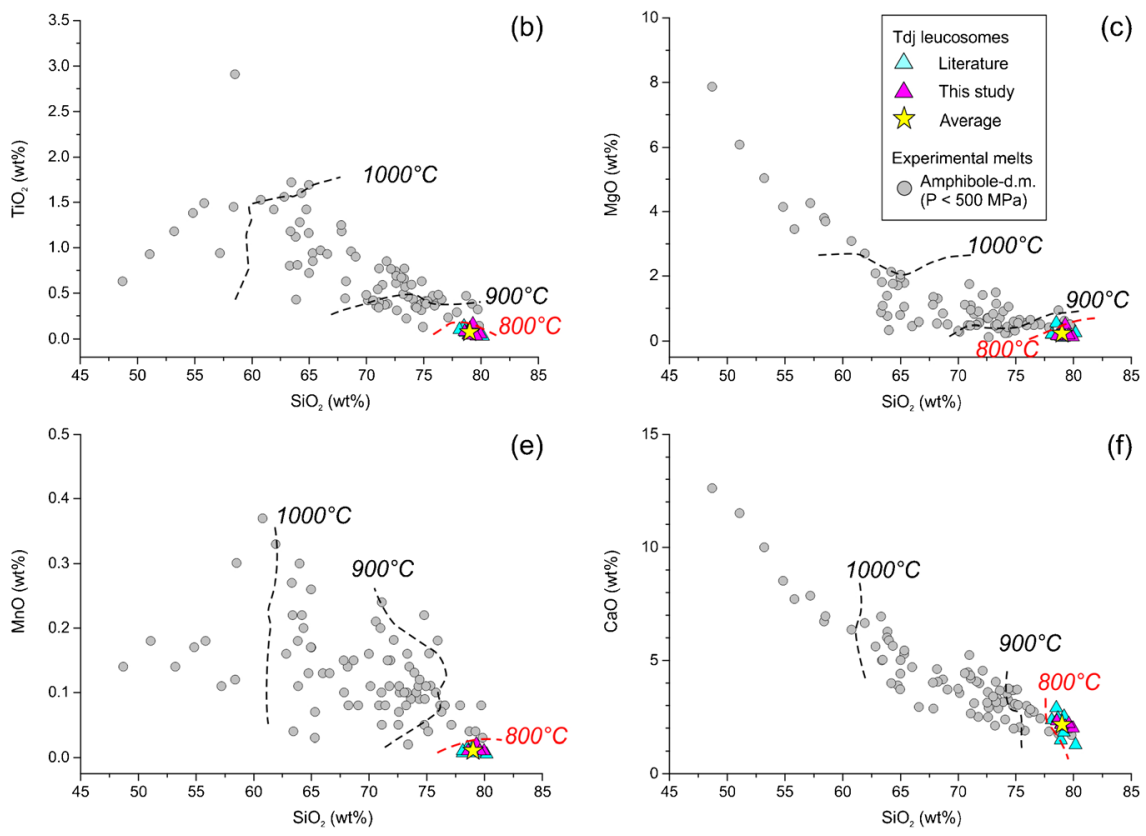

(h)

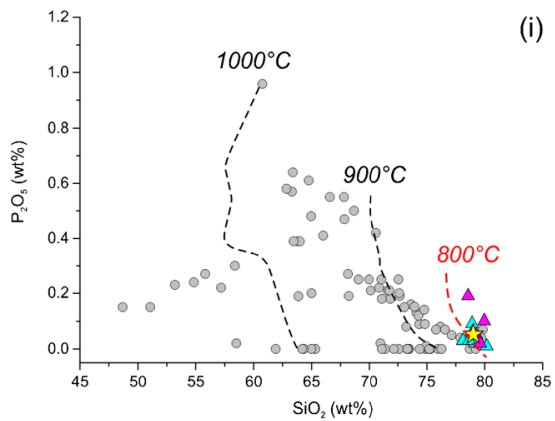

\section{Conclusions}

The hornblende-bearing gabbros outcropping at CheshmehGhasaban locality are a key area to investigate mafic migmatites and amphibole-controlled anatexis developed in the upper crust. Outcomes of this work are the following:

(i) The CG Hbl-gabbro are the source protolith of a mafic metatexite hosting up to $10 \mathrm{vol} \%$ of in situ high- $\mathrm{SiO}_{2}$ low- $\mathrm{Al}_{2} \mathrm{O}_{3}$ trondhjemites.

(ii) The EBM modelling indicates that the trondhjemite leucosomes are generated by a very low $(<2 \%)$ degree of batch melting of the hornblende-bearing gabbroic protolith.

(iii) The partial melting event were mainly controlled by primary $\mathrm{Pl}+\mathrm{Hbl}+\mathrm{Cpx}$ gabbroic assemblage, whereas Bt shows a negligible role and Opx does not participated to the anatexis. the integration of experimental melts and studied natural leucosomes. Literature data for trondhjemite (Tdj) leucosomes are from Saki et al. (2021). Experimental melt chemistry data (grey circles) are from Beard and Lofgren 1991; Sisson and Grove 1993; Patiño Douce and Beard 1995; Springer and Seck 1997; López and Castro 2001; Gao et al. 2016 (iv) The $\mathrm{Pl}$ is the main phase controlling Sr (LILE) content, whereas $\mathrm{Hbl}$ is deputy to regulating $\mathrm{Y}$ (HFSE) and $\mathrm{Yb}$ (HREE) contents; Cpx shows similar behavior of $\mathrm{Hbl}$; however, due to the lower distribution coefficients $\left({ }^{C p x} D \ll<{ }^{H b l} D\right)$, it plays a minor role with respect to the $\mathrm{Pl}+\mathrm{Hbl}$ assemblage.

(v) Classic and forward modelling thermobarometry along with existing literature indicates thermobaric estimates of $\mathrm{T} \approx 720-730^{\circ} \mathrm{C}$ at $\mathrm{P} \approx 360 \mathrm{MPa}$, close to the solidus, for the Hbl-gabbro partial melting and genesis of the trondhjemites.

(vi) The pseudosection method confirms the main role of $\mathrm{Pl}+\mathrm{Hbl}$ and highlights the growth of peritectic $\mathrm{Cpx}+$ Opx associated with the melt, coherently with Hbldominated melting reactions.

(vii) The natural CG high- $\mathrm{SiO}_{2}$ low- $\mathrm{Al}_{2} \mathrm{O}_{3}$ trondhjemites match the expected chemistry for melts generated by 
amphibole-dominated partial melting of a mafic source at $T<800^{\circ} \mathrm{C}$ and $P<500 \mathrm{MPa}$.

These results fully describe how trondhjemites can be generated by a low-temperature incipient melting controlled by $\mathrm{Ca}-\mathrm{Al}$-bearing $\mathrm{Pl}+\mathrm{Hbl}$ assemblage of a hornblende-bearing mafic source in upper crust conditions.

Acknowledgements We gratefully thank J. Connolly for the useful advice during the manuscript preparation. F. L. and A. R. gratefully acknowledge Claudio Faccenna and the grant to Department of Science, Roma Tre University (MIUR-Italy Dipartimenti di Eccellenza, ARTICOLO 1, COMMI 314 - 337 LEGGE 232/2016) and the PRIN2017 Project 20177BX42Z_001 (intraplate deformation, magmatism, and topographic evolution of a diffuse collisional belt: insights into the geodynamics of the Arabia-Eurasia collisional zones) funded by MIUR-Italy. A. S. and M. M. acknowledge the grant No. SCU.EG99.44295 funded by Shahid Chamran University of AhvazIran. The constructive reviews of two anonymous reviewers as well as the professional handling of the Editor Abdullah M. Al-Amri greatly contributed to improve the manuscript.

Funding Open access funding provided by Università degli Studi Roma Tre within the CRUI-CARE Agreement. This research is part of the corresponding author postdoc programme at the Roma Tre University. This research was supported by the PRIN2017 Project 20177BX42Z 001 (intraplate deformation, magmatism and topographic evolution of a diffuse collisional belt: Insights into the geodynamics of the Arabia-Eurasia collisional zones) funded by MIUR-Italy. The research was also supported by Shahid Chamran University of Ahvaz (grant nos. EG98.44295 and SCU.EG98.44295).

\section{Declarations}

Competing interests The authors declare that they have no competing interests.

Open Access This article is licensed under a Creative Commons Attribution 4.0 International License, which permits use, sharing, adaptation, distribution and reproduction in any medium or format, as long as you give appropriate credit to the original author(s) and the source, provide a link to the Creative Commons licence, and indicate if changes were made. The images or other third party material in this article are included in the article's Creative Commons licence, unless indicated otherwise in a credit line to the material. If material is not included in the article's Creative Commons licence and your intended use is not permitted by statutory regulation or exceeds the permitted use, you will need to obtain permission directly from the copyright holder. To view a copy of this licence, visit http://creativecommons.org/licenses/by/4.0/.

\section{References}

Agard P, Omrani J, Jolivet L, Mouthereau F (2005) Convergence history across. Zagros (Iran): constraints from collisional and earlier deformation: International Journal of Earth Sciences 94(3):401-419. https://doi.org/10.1007/s00531-005-0481-4

Aliani F, Maanijou M, Sabouri Z, Sepahi AA (2012) Petrology, geochemistry and geotectonic environment of the Alvand Intrusive
Complex. Hamedan, Iran: Chemie der Erde-Geochemistry 72: 363-383. https://doi.org/10.1016/j.chemer.2012.05.001

Azizi H, Stern RJ (2019) Jurassic igneous rocks of the central SanandajSirjan zone (Iran) mark a propagating continental rift, not a magmatic arc. Terra Nova 31(5):415-423

Azizi H, Mohammadi K, Asahara Y, Tsuboi M, Daneshvar N, Mehrabi B (2016) Strongly peraluminous leucogranite (Ebrahim-Attar granite) as evidence for extensional tectonic regime in the Cretaceous. Sanandaj Sirjan zone, northwest Iran: Chemie der ErdeGeochemistry 76:529-541. https://doi.org/10.1016/j.chemer.2016. 08.006

Azizi H, Lucci F, Stern RJ, Hasannejad S, Asahara Y (2018a) The Late Jurassic Panjeh submarine volcano in the northern Sanandaj-Sirjan Zone, northwest Iran: mantle plume or active margin. Lithos 308: 364-380. https://doi.org/10.1016/j.lithos.2018.03.019

Azizi H, Nouri F, Stern RJ, Azizi M, Lucci F, Asahara Y, Zarinkoub MH, and Chung SL, 2018b, New evidence for Jurassic continental rifting in the northern Sanandaj Sirjan Zone, western Iran: the Ghalaylan seamount, southwest Ghorveh: International Geology Review, p. 123. https://doi.org/10.1080/00206814.2018.1535913

Badr A, Davoudian AR, Shabanian N, Azizi H, Asahara Y, Neubauer F, Dong Y, Yamamoto K (2018) A-and I-type metagranites from the North Shahrekord Metamorphic Complex, Iran: evidence for Early Paleozoic post-collisional magmatism. Lithos 300:86-104

Baharifar A, Moinevaziri H, Bellon H, Piqué A (2004) The crystalline complexes of Hamadan (Sanandaj-Sirjan zone, western Iran): metasedimentary Mesozoic sequences affected by late cretaceous tectono-metamorphic and plutonic events. Compt Rendus Geosci 336:1443-1452. https://doi.org/10.1016/j.crte.2004.09.014

Barker, F., 1979, Trondhjemite: definition, environment, and hypotheses of origin, in Barker, F., ed., Trondhjemites, dacites and related rocks: Amsterdam, Elsevier, p. 1-11.

Barker E, Arth JG (1976) Generation of trondhjemitic tonalitic liquids and Archean bimodal trondhjemite-basalt suites. Geology 4:596600. https://doi.org/10.1130/0091-7613(1976)4<596:gotlaa>2.0. co; 2

Beard JS, Lofgren GE (1991) Dehydration melting and water-saturated melting of basaltic and andesitic greenstones and amphibolites at 1 , 3, and 6.9 kbar. J Petrol 32:365-401. https://doi.org/10.1093/ petrology/32.2.365

Bryan WB, Finger LT, Chayes F (1969) Estimating proportions in petrographic mixing equations by least-squares approximation. Science 163(3870):926-927

Castro A (2013) Tonalite-granodiorite suites as cotectic systems: a review of experimental studies with applications to granitoid petrogenesis. Earth Sci Rev 124:68-95

Castro A, Patiño Douce AE, Corretge LG, de la Rosa JD, El Biad M, El Hmidi H (1999) Origin of peraluminous granites and granodiorites. Iberian massif, Spain: an experimental test of granite petrogenesis: Contributions to Mineralogy and Petrology 135:255-276. https:// doi.org/10.1007/s004100050511

Chiu HY, Chung SL, Zarrinkoub M, Mohammadi SS, Khatib MM, Iizuka Y (2013) Zircon U-Pb age constraints from Iran on the magmatic evolution related to Neotethyan subduction and Zagros orogeny. Lithos 162-163:70-87. https://doi.org/10.1016/j.lithos.2013. 01.006

Clemens JD (1990) The granulite-granite connexion. In: Vielzeuf D, Vidal P (eds) Granulites and crustal differentiation. Kluwer Academic Publishers, Dordrecht, pp 25-36

Clemens JD, Stevens G (2012) What controls chemical variation in granitic magmas? Lithos 134-135:317-329. https://doi.org/10.1016/j. lithos.2012.01.001

Clemens, J.D., and Watkins, J.M., 2001, The fluid regime of hightemperature metamorphism during granitoid magma genesis: contributions to Mineralogy and Petrology, v. 140, p. 600-606. doi: https://doi.org/10.1007/s004100000205 
Connolly JAD (2005) Computation of phase equilibria by linear programming: a tool for geodynamic modeling and its application to subduction zone decarbonation. Earth Planet Sci Lett 236:524-541. https://doi.org/10.1016/j.epsl.2005.04.033

Conrad WK, Nicholls IA, Wall VJ (1988) Water-saturated and undersaturated melting of metaluminous and peraluminous crustal compositions at 10 kbar: evidence for the origin of silicic magmas in the Taupo Volcanic Zone, New Zealand, and other occurrences. J Petrol 29:765-803. https://doi.org/10.1093/petrology/29.4.765

Dale J, Powell R, White RW, Elmer FL, Holland TJB (2005) A thermodynamic model for Ca-Na clinoamphiboles in $\mathrm{Na}_{2} \mathrm{O}-\mathrm{CaO}-\mathrm{FeO}-$ $\mathrm{MgO}-\mathrm{Al}_{2} \mathrm{O}_{3}-\mathrm{SiO}_{2}-\mathrm{H}_{2} \mathrm{O}-\mathrm{O}$ for petrological calculations. J Metamorph Geol 23:771-791. https://doi.org/10.1111/j.15251314.2005.00609.x

Eftekharnejad J (1981) Tectonic division of Iran with respect to sedimentary basins (in Persian). J Iran Petrol Soc 82:19-28

Eghlimi B 1998, Geological map of Iran 1:100.000 Sheet 5759 "Hamadan": Geological Survey of Iran, 1 sheet.

Ersoy EY (2013) PETROMODELER (Petrological Modeler): a Microsoft@ Excel@ spreadsheet program for modelling melting, mixing, crystallization and assimilation processes in magmatic systems. Turk J Earth Sci 22(1):115-125

Eshraghi, S.A., Mahmoudi Gharai, M., 2003, Geological map of Iran 1: 100.000 Sheet 5659 “Tuyserkan": Geological Survey of Iran, 1 sheet.

Fuhrman ML, Lindsley DH (1988) Ternary feldspar modeling and thermometry. Am Mineral 73:201-215. https://doi.org/10.1007/ bf00379455

Gao P, Zheng YF, Zhao ZF (2016) Experimental melts from crustal rocks: a lithochemical constraint on granite petrogenesis. Lithos 266-267:133-157. https://doi.org/10.1016/j.lithos.2016.10.005

García-Arias M, Corretge LG, Castro A (2012) Trace element behavior during partial melting of Iberian orthogneisses: an experimental study. Chem Geol 292-293:1-17. https://doi.org/10.1016/j. chemgeo.2011.10.024

García-Casco A, Lázaro C, Torres-Roldán RL, Núñez Cambra K, Rojas Agramonte Y, Kröner A, Neubauer F, Millán G, Blanco Quintero I (2008) Partial melting and counterclockwise P-T path of subducted oceanic crust (Sierra del Convento mélange, Cuba). J Petrol 49:129_ 161

Ghasemi A, Talbot CJ (2006) A new tectonic scenario for the SanandajSirjan Zone (Iran). J Asia Earth Sci 26:683-693. https://doi.org/10. 1016/j.jseaes.2005.01.003

Graphchikov AA, Konilov AN, Clemens JD (1999) Biotite dehydration, partial melting, and fluid composition: experiments in the system $\mathrm{KAlO} 2-\mathrm{FeO}-\mathrm{MgO}-\mathrm{SiO} 2-\mathrm{H} 2 \mathrm{O}-\mathrm{CO} 2$. Am Mineral 84(1-2):15-26

Green ECR, White RW, Diener JFA, Powell R, Holland TJB, Palin RM (2016) Activity-composition relations for the calculation of partial melting equilibria in metabasic rocks. J Metamorph Geol 34:845869. https://doi.org/10.1111/jmg.12211

Hassanzadeh J, Wernicke B (2016) The Neotethyan Sanadaj-Sirjan zone of Iran as an archetype for passive margin-arc transitions. Tectonics 35:586-621. https://doi.org/10.1002/2015tc003926

Hassanzadeh J, Stockli DF, Horton BK, Axen GJ, Stockli LD, Grove M, Schmitt AK, Walker JD (2008) U-Pb zircon geochronology of late Neoproterozoic-Early Cambrian granitoids in Iran: implications for paleogeography, magmatism, and exhumation history of Iranian basement. Tectonophysics 451:71-96. https://doi.org/10.1016/j. tecto.2007.11.062

Holland TJB, Powell R (2003) Activity-composition relations for phases in petrological calculations: an asymmetric multicomponent formulation. Contrib Mineral Petrol 145(4):492-501

Holland TJB, Powell R (2011) An improved and extended internally consistent thermodynamic dataset for phases of petrological interest, involving a new equation of state for solids. J Metamorph Geol 29(3):333-383
Hosseini SA, Afzal P, Sadeghi B, Shahrokhi SV, Farhadinejad T (2015) Prospection of $\mathrm{Au}$ mineralization based on stream sediments and lithogeochemical data using multifractal modeling in Alut 1:100, 000 sheet. NW Iran: Arabian Journal of Geosciences v 8:38673879. https://doi.org/10.1007/s12517-014-1436-5

Hu ZP, Zhang YS, Hu R, Wang J, Siebel W, Chen F (2016) Amphibolebearing migmatite in North Dabie, eastern China: Water-fluxed melting of the orogenic crust. J Asian Earth Sci 125:100116. https://doi.org/10.1016/j.jseaes.2016.05.018

Johannes W, Holtz F (1996) Petrogenesis and experimental petrology of granitic rock: Berlin. Springer Press, Heidelberg, p 335

Koepke J, Feig ST, Snow JE (2005) Hydrous partial melting within the lower oceanic crust. Terra Nova 17:286-291. https://doi.org/10. 1111/j.1365-3121.2005.00613.x

Kriegsman L (2001) Partial melting, partial melt extraction and partial back reaction in anatectic migmatites. Lithos 56:75-96. https://doi. org/10.1016/S0024-4937(00)00060-8

Laurie A, Stevens G (2012) Water-present eclogite melting to produce Earth's early felsic crust. Chem Geol 314-317:83-95. https://doi. org/10.1016/j.chemgeo.2012.05.001

Le Maitre RW, Streckeisen A, Zanettin B, Le Bas MJ, Bonin B, Bateman P, Bellieni G, Dudek A, Efremova S, Keller J, Lameyre J, Sabine PA, Schmid R, Sqrensen H, Woolley AR (2002) Igneous rocks a classification and glossary of terms recommendations of the International Union of Geological Sciences, Sub-Commission on the Systematics of Igneous Rocks: Cambridge University Press. UK, Cambridge, p 236

López S, Castro A (2001) Determination of the fluid-absent solidus and supersolidus phase relationships of MORB-derived amphibolites in the range 4-14 kbar. Am Mineral 86:1396-1403. https://doi.org/10. 2138/am-2001-11-1208

Lucci F, Rossetti F, White JC, Moghadam HS, Shirzadi A, Nasrabady M (2016) Tschermak fractionation in calc-alkaline magmas: the Eocene Sabzevar volcanism (NE Iran). Arab J Geosci 9(10):573. https://doi.org/10.1007/s12517-016-2598-0

Lucci F, Rossetti F, Becchio R, Theye T, Gerdes A, Opitz J, Baez W, Bardelli L, De Astis G, Viramonte J, Giordano G (2018) Magmatic Mn-rich garnets in volcanic settings: age and longevity of the magmatic plumbing system of the Miocene Ramadas volcanism (NW Argentina). Lithos 322:238-249. https://doi.org/10.1016/j.lithos. 2018.10.016

Mahmoudi S, Corfu F, Masoudi F, Mehrabi B, Mohajjel M (2011) U-Pb dating and emplacement history of granitoid plutons in the northern Sanandaj-Sirjan Zone. Iran: Journal of Asian Earth Sciences 41: 238-249. https://doi.org/10.1016/j.jseaes.2011.03.006

Malek-Mahmoudi F, Davoudian AR, Shabanian N, Azizi H, Asahara Y, Neubauer F, Dong Y (2017) Geochemistry of metabasites from the North Shahrekord metamorphic complex, Sanandaj-Sirjan Zone: geodynamic implications for the Pan-African basement in Iran. Precambrian Res 293:56-72. https://doi.org/10.1016/j.precamres. 2017.03.003

Middlemost EAK (1994) Naming materials in the magma/igneous rock system. Earth-Sci Rev 37:215-224. https://doi.org/10.1016/00128252(94)90029-9

Miller CF, McDowell SM, Mapes RW (2003) Hot and cold granites? Implications of zircon saturation temperatures and preservation of inheritance. Geology 31:529-532. https://doi.org/10.1130/00917613(2003)031<0529:HACGIO>2.0.CO;2

Moghadam HS, Li QL, Griffin WL, Stern RJ, Ishizuka O, Henry H, Lucci F, O'Reilly SY, Ghorbani G (2020) Repeated magmatic buildup and deep "hot zones" in continental evolution: the Cadomian crust of Iran. Earth Planet Sci Lett 531:115989. https://doi.org/10.1016/j. epsl.2019.115989

Moghadam HS, Li QL, Griffin WL, Stern RJ, Santos JF, Lucci F, Beyarslan M, Ghorbani G, Ravankhah A, Tilhac R, O'Reilly SY (2021) Prolonged magmatism and growth of the Iran-Anatolia 
Cadomian continental arc segment in Northern Gondwana. Lithos, 384:105940. https://doi.org/10.1016/j.lithos.2020.105940

Mohajjel M, Fergusson CL (2000) Dextral transpression in Late Cretaceous continental collision. Sanandaj-Sirjan zone, western Iran: J Structural Geol 22(8):1125-1139

Mohajjel M, Fergusson CL, Sahandi MR (2003) Cretaceous-Tertiary convergence and continental collision, Sanandaj-Sirjan zone, Western Iran. J Asian Earth Sci 21:397-412. https://doi.org/10. 1016/s1367-9120(02)00035-4

Montel JM (1993) A model for monazite/melt equilibrium and application to the generation of granitic magmas. Chem Geol 110:127-146. https://doi.org/10.1016/0009-2541(93)90250-m

Montel JM, and Vielzeuf D, (1997), Partial melting of metagreywackes, part II. Compositions of minerals and melts: contributions to Mineralogy and Petrology, v. 128, p. 176-196. doi:https://doi.org/ $10.1007 / \mathrm{s} 004100050302$

Moyen J, Stevens G (2006) Experimental constraints on TTG petrogenesis: implications for Archean geodynamics. In: Benn K, Mareschal J-C, Condie KC (eds) Archean Geodynamics and Environments, Geophysical Monograph Series-American Geophysical Union, vol 164, pp 149-175. https://doi.org/10.1029/164GM11

Nilsen O, Sundvoll B, Roberts D, Corfu F (2003) U-Pb geochronology and geochemistry of trondhjemites and a norite pluton from the SW Trondheim Region, Central Norwegian Caledonides. Norges Geol Unders Bull 441:5-16

Patiño Douce AE (1999) What do experiments tell us about the relative contributions of crust and mantle to the origin of granitic magmas. In: Castro A, Fernandez C, Vigneresse JL (eds) Understanding Granites: Integrating New and Classical Techniques, Geological Society, vol 168. Special Publications, London, pp 55-75

Patiño Douce AE, Beard JS (1995) Dehydration-melting of biotite gneiss and quartz amphibolite from 3 to 15 kbar. J Petrol 36:707-738. https://doi.org/10.1093/petrology/36.3.707

Pattison DRM (1991) Infiltration-driven dehydration and anatexis in granulite facies metagabbro, Grenville Province, Ontario, Canada. J Metamorph Geol 9(3):315-332

Rabiee A, Rossetti F, Asahara Y, Azizi H, Lucci F, Lustrino M, Nozaem R (2020) Long-lived, Eocene-Miocene stationary magmatism in NW Iran along a transform plate boundary. Gondwana Res 85: 237-262

Ratajeski K, Glazner AF, Miller BV (2001) Geology and geochemistry of mafic to felsic plutonic rocks associated with the intrusive suite of Yosemite Valley. California: Geol Soc America Bullet 113:14861502. https://doi.org/10.1130/0016-7606(2001)113<1486: GAGOMT>2.0.CO;2

Ratajeski K, Sisson TW, Glazner AF (2005) Experimental and geochemical evidence for derivation of the El Capitan Granite. California, by partial melting of hydrous gabbroic lower crust: Contributions to Mineralogy and Petrology 149:713-734. https://doi.org/10.1007/ s00410-005-0677-4

Rossetti F, Dini A, Lucci F, Bouybaouene M, Faccenna C (2013) Early Miocene strike-slip tectonics and granite emplacement in the Alboran Domain (Rif Chain, Morocco): significance for the geodynamic evolution of Western Mediterranean. Tectonophysics 608:774-791. https://doi.org/10.1016/j.tecto.2013.08.002.

Rossetti F, Nasrabady M, Theye T, Gerdes A, Monie P, Lucci F, Vignaroli G (2014) Adakite differentiation and emplacement in a subduction channel: the late Paleocene Sabzevar magmatism (NE Iran). Geol Soc Am Bull 126:317-343. https://doi.org/10.1130/ b30913.1

Rossetti F, Lucci F, Theye T, Bouybaouenne M, Gerdes A, Opitz J, Dini A, Lipp C (2020) Hercynian anatexis in the envelope of the Beni Bousera peridotites (Alboran Domain, Morocco): implications for the tectono-metamorphic evolution of the deep crustal roots of the Mediterranean region. Gondwana Res 83:157-182. https://doi.org/ 10.1016/j.gr.2020.01.020
Rushmer T (1991) Partial melting of two amphibolites: contrasting experimental results under fluid-absent conditions. Contrib Mineral Petrol 107(1):41-59

Saki A, Moazzen M, Baharifar A (2012) Migmatite microstructures and partial melting of Hamadan metapelitic rocks, Alvand contact aureole, western Iran. Int Geol Rev 54:1229-1240. https://doi.org/10. 1080/00206814.2011.636639

Saki, A., Miri, M., and Oberhänsli, R., 2020, High temperature - low pressure metamorphism during subduction of Neo-Tethys beneath the Iranian plate: evidence for mafic migmatite formation in the Alvand complex (western Iran): Mineralogy and Petrology, doi: https://doi.org/10.1007/s00710-020-00721-z

Saki A, Lucci F, Miri M, White JC (2021) Trondhjemite leucosomes generated by partial melting of a hornblende-gabbro (Alvand plutonic complex, Hamedan, NW Iran). Int Geol Rev 1-34:1-34. https://doi.org/10.1080/00206814.2020.1861554

Sawyer EW (2008) Atlas of Migmatites: the Canadian Mineralogist Special Publication 9. National Research Press, Ottawa, Canada, $p$ 371

Sepahi AA (2008), Typology and petrogenesis of granitic rocks in the Sanandaj-Sirjan metamorphic belt, Iran: with emphasis on the Alvand plutonic complex: Neues Jahrbuch für Geologie und Paläontologie-Abhandlungen, v. 247, p. 295-312. doi:https://doi. org/10.1127/0077-7749/2008/0247-0295

Sepahi AA, Jafari SR, Mani-Kashani S (2009) Low pressure migmatites from the Sanandaj-Sirjan Metamorphic Belt in the Hamedan region Iran. Geol Carpath 602:107-119. https://doi.org/10.2478/v10096009-0007-2

Sepahi AA, Borzoei K, Salami S (2013) Mineral chemistry and thermobarometry of plutonic, metamorphic and anatectic rocks from the Tueyserkan area (Hamedan, Iran). Geological Quarterly 57(3): $515-526$

Sepahi AA, Salami S, Lentz D, McFarlane C, Maanijou M (2018) Petrography, Geochemistry and U-pb geochronology of pegmatites and aplites associated with the Alvand intrusive complex in the Hamedan Region, Sanandaj-sirjan Zone, Zagros Orogen (Iran). Int J Earth Sci 107:1059-1096. https://doi.org/10.1007/s00531-017$1515-4$

Sepahi AA, Jafari SR, Osanai Y, Shahbazi H, Moazzen M (2019) Age, petrologic significance and provenance analysis of the Hamedan low pressure migmatites, Sanandaj-Sirjan zone, west Iran. Int Geol Rev 61:1446-1461. https://doi.org/10.1080/00206814.2018. 1517392

Sepahi AA, Vahidpour H, Lentz DR, McFarlane CM, Maanijou M, Salami S, Miri M, Mansouri M, Mohammadi R (2020) Rare sapphire-bearing syenitoid pegmatites and associated granitoids of the Hamedan region, Sanandaj-Sirjan zone, Iran: analysis of petrology, lithogeochemistry and zircon geochronology / trace element geochemistry. Geol Mag 157:1499-1525. https://doi.org/10.1017/ S0016756820000023

Shahbazi H, Siebel W, Pourmoafee M, Ghorbani M, Sepahi AA, Shang CK, Abedini MV (2010) Geochemistry and U-Pb zircon geochronology of the Alvand plutonic complex in Sanandaj-Sirjan Zone (Iran): new evidence for Jurassic magmatism. J Asian Earth Sci 39:668-683. https://doi.org/10.1016/j.jseaes.2010.04.014

Shahbazi H, Salami S, Siebel W (2014) Genetic classification of magmatic rocks from the Alvand plutonic complex, Hamedan, western Iran, based on zircon crystal morphology. Chemie der ErdeGeochemistry 74:577-584. https://doi.org/10.1016/j.chemer.2013. 11.001

Shaw GE (1970) A summary of lightning current measurements collected at Mount Lemmon, Arizona. J Geophys Res 75:2159-2164. https:// doi.org/10.1029/JC075i012p02159 issn: 0148-0227

Sheikhi Gheshlaghi R, Ghorbani M, Sepahi AA, Deevsalar R, and Shinjo $R$, (2020), Petrogenesis of gem sapphire in a pegmatite-aplite vein 
from the Alvand batholith, Western Iran: Mineralogy and Petrology, doi:https://doi.org/10.1007/s00710-020-00716-w

Singh J, Johannes W (1996) Dehydration melting of tonalites. Part I Beginning of melting: contributions to mineralogy and petrology 125(1):16-25

Sisson TW, and Grove TL, (1993), Temperatures and H2O contents of low-MgO high-alumina basalts: contributions to Mineralogy and Petrology, v. 113, p. 167-184. doi:https://doi.org/10.1007/ bf00283226

Sisson TW, Ratajeski K, Hankins WB, and Glazner AF, (2005), Voluminous granitic magmas from common basaltic sources: contributions to Mineralogy and Petrology, v. 148, p. 635-661. doi: https://doi.org/10.1007/s00410-004-0632-9

Skjerlie KP, Johnston AD (1996) Vapour-absent melting from 10 to 20 kbar of crustal rocks that contain multiple hydrous phases: implications for anatexis in the deep to very deep continental crust and active continental margins. J Petrol 37:661-691. https://doi.org/10. 1093/petrology/37.3.661

Skjerlie KP, and Patiño Douce AE, (1995), Anatexis of interlayered amphibolite and pelite at 10 kbar: effect of diffusion of major components on phase relations and melt fraction: Contributions to Mineralogy and Petrology, v. 122, p. 62-78. doi:https://doi.org/10. 1007/s004100050113

Skjerlie KP, Patiño Douce AE (2002) The fluid-absent partial melting of a zoisite-bearing quartz eclogite from $1 \cdot 0$ to $3 \cdot 2 \mathrm{GPa}$; Implications for melting in thickened continental crust and for subduction-zone processes. J Petrol 43(2):291-314

Springer W, and Seck HA, 1997, Partial fusion of basic granulites at 5 to 15 kbar: Implications for the origin of TTG magmas: contributions to Mineralogy and Petrology, v. 127, p. 30-45. doi:https://doi.org/ $10.1007 / \mathrm{s} 004100050263$

Stöcklin J (1968) Structural history and tectonics of Iran: a review. Am Assoc Pet Geol Bull 52:1229-1258. https://doi.org/10.1306/ $5 \mathrm{~d} 25 \mathrm{c} 4 \mathrm{a} 5-16 \mathrm{c} 1-11 \mathrm{~d} 7-8645000102 \mathrm{c} 1865 \mathrm{~d}$

Stöcklin J, and Nabavi MH, 1973, Tectonic map of iran: geological survey of Iran, scale 1:2 500000 .

Streckeisen AL (1976) Classification and nomenclature of igneous rocks. Final report of an inquiry. Neues Jb Mineral Abh 107:144-240

Sun SS, McDonough WF (1989) Chemical and isotopic systematics of oceanic basalts: implications for mantle composition and processes. In: Saunders AD, Norry MJ (eds) Magmatism in the Ocean Basins, vol 42. The Geological Society of London, London, pp 313-345. https://doi.org/10.1144/gsl.sp.1989.042.01.19

Tajcmanova L, Connolly JAD, Cesare B (2009) A thermodynamic model for titanium, ferric iron solution in biotite. J Metamorph Geol 27: 153-165. https://doi.org/10.1111/j.1525-1314.2009.00812.x

Taylor J, Stevens G (2010) Selective entrainment of peritectic garnet into S-type granitic magmas: evidence from Archaean mid-crustal anatectites. Lithos 120(3-4):277-292

Thompson AB, Ellis DJ (1994) $\mathrm{CaO}+\mathrm{MgO}+\mathrm{Al} 2 \mathrm{O} 3+\mathrm{SiO} 2+\mathrm{H} 2 \mathrm{O}$ to 35 $\mathrm{kb}$; amphibole, talc, and zoisite dehydration and melting reactions in the silica-excess part of the system and their possible significance in subduction zones, amphibolite melting, and magma fractionation. Am J Sci 294(10):1229-1289

Vielzeuf D, and Montel JM, 1994, Partial melting of metagreywackes. Part I. Fluid-absent experiments and phase relationships: Contributions to Mineralogy and Petrology, v. 117, p. 375-393. doi:https://doi.org/10.1007/bf00307272

Vielzeuf D, and Vidal $\mathrm{Ph}$ (eds) (1990), Granulites and crustal differentiation: Kluwer Academic Publishers, Dordrecht, p. 601.

Watkins JM, Clemens JD, and Treloar PJ, 2007, Archaean TTGs as sources of younger granitic magmas: melting of sodic metatonalites at 0.6-1.2 GPa: contributions to Mineralogy and Petrology, v. 154, p. 91-110. doi:https://doi.org/10.1007/s00410-007-0181-0

Watson EB, Harrison TM (1983) Zircon saturation revisited: temperature and composition effects in a variety of crustal magma types. Earth Planet Sci Lett 64:295-304. https://doi.org/10.1016/0012-821X(83) 90211-X

Weinberg RF, Hasalová P (2015) Water-fluxed melting of the continental crust: a review. Lithos 212:158-188

White JC, Parker DF, Ren M (2009) The origin of trachyte and pantellerite from Pantelleria, Italy: insights from major element, trace element, and thermodynamic modelling. J Volcanol Geotherm Res 179(1):33-55

White RW, Powell R, Holland TJB, Johnson TE, Green ECR (2014) New mineral activity-composition relations for thermodynamic calculations in metapelitic systems. J Metamorph Geol 32:261-286. https:// doi.org/10.1111/jmg.12071

Whitney DL, Evans BW (2010) Abbreviations for names of rock-forming minerals. Am Mineral 95:185-187. https://doi.org/10.2138/am. 2010.3371

Yang TN, Chen JL, Liang MJ, Xin D, Aghazadeh M, Hou ZQ, Zhang HR (2018) Two plutonic complexes of the Sanandaj-Sirjan magmaticmetamorphic belt record Jurassic to Early Cretaceous subduction of an old Neo-Tethys beneath the Iran microplate. Gondwana Res 62: 246-268. https://doi.org/10.1016/j.gr.2018.03.016

Zhang H, Chen J, Yang T, Hou Z, Aghazadeh M (2018a) Jurassic granitoids in the northwestern Sanandaj-Sirjan zone: evolving magmatism in response to the development of a Neo-Tethyan slab window. Gondwana Res 62:269-286. https://doi.org/10.1016/j.gr. 2018.01.012

Zhang Z, Xiao W, Ji W, Majidifard MR, Rezaeian M, Talebian M, Xiang D, Chen L, Wan B, Ao S, Esmaeili R (2018b) Geochemistry, zircon $\mathrm{U}-\mathrm{Pb}$ and $\mathrm{Hf}$ isotope for granitoids, NW Sanandaj-Sirjan zone, Iran: implications for Mesozoic-Cenozoic episodic magmatism during Neo-Tethyan lithospheric subduction. Gondwana Res 62:227-245. https://doi.org/10.1016/j.gr.2018.04.002

Zou HB (1998) Trace element fractionation during modal and non-modal dynamic melting and open-system melting: a mathematical treatment. Geochim Cosmochim Acta 62:1937-1945 